This is an Accepted Manuscript of an article published in Global Crime on 21 February 2014, available online: http://www.tandfonline.com/10.1080/17440572.2014.882778

\title{
Mythical numbers and the proceeds of organized crime: Estimating the mafia proceeds in Italy
}

\section{Francesco Calderoni}

Università Cattolica del Sacro Cuore and Transcrime, Milan, Italy

\begin{abstract}
Organized crime is a field vulnerable to mythical numbers, i.e. exaggerated estimates lacking empirical support, but acquiring acceptance through repetition. The figures on mafia proceeds in Italy are a striking example of this problem. This study proposes an estimation of mafia proceeds in Italy from nine criminal activities (sexual exploitation of women, illicit firearms trafficking, drug trafficking, counterfeiting, the illicit cigarette trade, illicit gambling, illicit waste disposal, loan sharking, and extortion racketeering) by region and type of mafia (Cosa Nostra, Camorra, 'Ndrangheta, Apulian mafias, and other mafias). The results estimate yearly mafia proceeds at approximately $€ 10.7$ bn $(0.7 \%$ of the Italian GDP), discussing the impact on the regional and national economies and the differences among the types of mafias as to their geographical sources of revenues.
\end{abstract}

Keywords: proceeds of crime; mafia proceeds; Italian mafias; organized crime; estimating criminal revenues; criminal markets.

\section{Introduction}

Crime has always been the favorite field for the purveyors of mythical numbers. Mythical numbers are estimates of a phenomenon inevitably overstating its size while lacking empirical support. Nevertheless, they gain acceptance by policymakers, the media, public opinion and, sometimes, scholars due to their repetition "as gospel numbers that have no real basis in fact". ${ }^{1}$ Indeed, practitioners and academics in the crime field often know very well 
that "because an estimate has been used widely by a variety of people who should know what they are talking about, one cannot assume that the estimate is even approximately correct". ${ }^{2}$

According to Reuter, there are three main reasons for the success of mythical numbers. ${ }^{3}$ First, there is no constituency for accurate numbers, while there is interest in keeping figures high. Second, scholars in the field may have no interest in correct estimations. Third, and most importantly, mythical numbers persist because they have almost no impact on policies.

The vitality of mythical numbers is attributable to the increasing importance of quantification for public policies. The advancement of sciences in different domains has improved mankind's capacity to measure natural and social phenomena. Increasingly, figures are the main subject of policy debates, and there is increasing demand for evidence-based policies. This generates its own supply of estimates which, "particularly in newer areas of policy making, are frequently of poor quality and difficult to evaluate". 4

Almost thirty years ago, Reuter claimed that such figures have scant impact on actual policies, but he also predicted that the trend would increase further. He also argued that the problem is difficult to prevent, due to governments' need to back up their claims with (any) evidence; the self-driving appetite of public agencies for resources; the difficulty of refuting bad estimates with better ones (particularly in new policy areas); and the uncritical exploitation of mythical numbers by politicians, policymakers, and stakeholders in general. ${ }^{5}$

Notwithstanding the development of criminology in recent years, it is hard to argue that the above arguments are today devoid of any relevance. Mythical numbers still enjoy great success as new crime threats develop: consider the frequent alarming claims by public agencies and by private businesses on the threats of cybercrime. ${ }^{6}$

The field of organized crime is even more exposed to mythical numbers. Since its early stages, the public and scholarly debate on organized crime has been affected by 
unsubstantiated claims devoid of empirical support. The notion of organized crime gained public importance throughout the twentieth century due to political pressures, simplifications, and stereotypes. After the end of WWII, organized crime in the US was depicted as an alien conspiracy by a small number of Sicilian or Italian mafiosi, and this stereotype is still very common. ${ }^{7}$ Despite the criticisms of scholars, the concept was successfully exported to other countries with strategies of moral panic and securitization. ${ }^{8}$ At the same time, the general understanding of organized crime remained vague, with scholars discussing its social construction, mystique and paradoxes. ${ }^{9}$

The attempts by national and international institutions to address and quantify organized crime met with criticism by academics. ${ }^{10}$ The media and public opinion are still strongly influenced by mythical numbers on organized crime. For example, a 2011 study by the United Nations Office on Drugs and Crime (UNODC) reviewed a number of estimates of money-laundering and identified a consensus share of world GDP equal to US\$870 bn in 2009. ${ }^{11}$ While the report was cautious about the reliability of the estimates, the figure rapidly became a mythical number. UNODC's Director declared "We are able to quantify the cost of transnational organized crime, it is US $\$ 870$ billion, but we cannot calculate the misery and suffering caused to millions of people by these illicit activities". ${ }^{12}$ The UN agency also launched a public awareness campaign which received worldwide media attention. ${ }^{13}$

The persistence of mythical numbers about organized crime shows most of the features already mentioned. A small, but well-organized, constituency of governments, international organizations, and non-governmental agencies has an interest in keeping such numbers high, while the interest in accurate estimates is widespread among citizens. ${ }^{14}$ Debunking such mythical numbers is difficult and unrewarding - any criticisms may be perceived as attempts to minimize the issue of organized crime. ${ }^{15}$ Policies are only marginally affected by the estimates. Governments are unable to measure the performance of such 
policies, so that there is limited interest in questioning the mythical numbers about organized crime.

This situation entails several negative consequences. These numbers may disseminate stereotypes in the population, stimulate xenophobia, heighten the fear of crime, and distort perceptions of what the real problems are. They may ultimately affect the establishment of effective and efficient policies to reduce organized crime.

The long-term solution to the problem may be the integration of estimates of organized crime activities into the policy process. ${ }^{16}$ However, this requires establishment of a number of preconditions addressing the causes of the persistence of mythical numbers. Data collection on organized crime should improve; estimation methodologies should be transparent; and scholars should participate in the process more actively than they are currently willing. These preconditions may contribute to informing public opinion and making the success of mythical numbers less likely.

Considering that "it is easy to point to the failings of the first 'measurement' but often hard to produce a convincing alternative" ${ }^{, 17}$, this article opts for the hard path. It tackles the problems of estimating the proceeds of organized crime with an attempt to estimate the revenues of the mafias in Italy which uses a specifically designed method. It addresses questions such as: What is the income of the mafias in Italy? How is it distributed across Italian regions and types of mafia? The study is inspired by a research project conducted by Transcrime for the Italian Ministry of Interior, which analyzed investments by mafias in Italy and abroad. ${ }^{18}$ The results estimate yearly mafia proceeds at approximately $€ 10.7$ bn $(0.7 \%$ of the Italian GDP), with extortion racketeering as the main source of income. Camorra and 'Ndrangheta are the mafias with the highest revenues (€3,3 bn and nearly $€ 3$ bn, respectively), totaling more than $68 \%$ of total mafia proceeds. Also, the 'Ndrangheta has 
successfully diversified its source of income, with only $28 \%$ of the revenues coming from the native region (Calabria).

The other sections of the article are organized as follows: the next section discusses mythical numbers about mafia proceeds in Italy. The third section describes the methodology and its limitations, while the fourth one presents and discusses the results. The last section concludes.

\section{Mafia mythical numbers in Italy}

Despite the abundant literature on mafias, in the past decade mythical numbers have gained increasing importance in Italy. While public institutions have traditionally refrained from producing estimates, mythical numbers have developed as a result of the misinterpretation and uncritical repetition of figures developed by a few academic studies and non-governmental organizations.

The most frequently cited mythical numbers on the mafias in Italy are two estimates of their proceeds or revenues. The first mythical number states that mafia revenues amount to approximately $€ 150$ bn yearly, and it is frequently attributed to the Bank of Italy, the country's central bank. The second mythical number is $€ 138 \mathrm{bn}$, which allegedly corresponds to the annual turnover of the so-called "Mafia Inc." and was created by SOS Impresa, a nongovernmental association of entrepreneurs against extortion racketeering. The account of the birth and evolution of these figures provides impeccable examples of the problems of mythical numbers. ${ }^{19}$

The $€ 150$ bn number is approximately $10 \%$ of Italy's GDP, and it originated from studies, published in academic journals and in a paper series of the Bank of Italy, measuring the underground and illegal economy by means of econometric models. In 2008, Argentiero et al. estimated the money laundered yearly from 1981 to 2001 at approximately $12 \%$ of

Italian GDP. ${ }^{20}$ In 2012, Ardizzi and colleagues estimated the underground economy from the 
demand for cash (using the ratio between withdrawals from current accounts and non-cash payments as the dependent variable). ${ }^{21}$ For the period 2005-2008, the study estimated the underground and criminal economy at $16.5 \%$ and $10.9 \%$ of GDP, respectively. Estimation of the criminal economy was based on reported drug trafficking and exploitation of prostitution offences. Whilst the study adopted an interesting macroeconomic approach, the variables for the criminal economy raise questions about their reliability. As well known, official statistics on these offences have a high "dark" number. Reports mostly depend on the priorities and intensity of activity of the law enforcement agencies and on the more or less prohibitionist stances taken by governments towards drugs and prostitution. Given these considerations, the resulting estimates should have been treated with extreme caution. A subsequent development of the study by the same authors using a different model produced substantially lower estimates (money laundering by the criminal economy was assessed at between $6.6 \%$ and $8 \%$ of GDP). ${ }^{22}$ Nevertheless, the numbers were cited (along with others) by Anna Maria Tarantola, the Deputy Governor of the Bank of Italy, at a hearing of 6 June 2012 before the Parliamentary Antimafia Commission. Tarantola declared that "evaluations that have used different methodologies must be analyzed with extreme caution; they may suggest the huge economic importance of the phenomenon, but they do not allow accurate calculation". ${ }^{23}$ Notwithstanding Tarantola's cautions, the machine generating a mythical number soon started. The Antimafia Commission classified the total amount of $€ 150$ bn as the "annual turnover of domestic mafias", attributing it to "the police and various institutions". ${ }^{24}$ Thus the original estimate, which referred to the criminal economy in general, was already being attributed to organized crime alone. In March 2012, the European Commission, on proposing a new EU Directive on proceeds of crime, stated that "there are no reliable estimates of the size of criminal profits in the European Union, but in Italy the proceeds of organised crime laundered in 2011 have been estimated by the Bank of Italy at $€ 150$ bn". ${ }^{25}$ A video produced 
by the Directorate General Home Affairs of the European Commission stated that "in Italy organized crime revenues have been estimated at $€ 150 \mathrm{bn"} .{ }^{26}$ The international media promptly leapt on the news. The figure enjoyed wide success and was attributed to the UN or the Bank of Italy, or it was just unreferenced. ${ }^{27}$

The $€ 138$ bn number comes from the thirteenth edition of the report entitled The Hands of Criminality on Enterprises (Le mani della criminalità sulle imprese) by SOS Impresa, a non-governmental association campaigning against the mafias. In its ninth report of 2006, SOS Impresa provocatively coined the expression Mafia SpA (i.e. "Mafia Inc."). ${ }^{28}$ The thirteen report of 2012 estimated Mafia Spa’s yearly revenues for 2010 at $€ 138.09$ bn, with profits amounting to $€ 104.70$ bn and cash assets to $€ 65.64 \mathrm{bn}^{29}$ The report did not clarify its methodology, raising a number of doubts about its reliability. For example, drug trafficking yearly revenues - the prime source of income for the Mafia SpA - were estimated at $€ 65 \mathrm{bn}$. This figure is higher than other national estimates (ranging between $€ 6$ and $€ 9$ bn euros, in only two cases reaching $€ 23 \mathrm{bn}$; see the article on drug trafficking in this double special issue) and even higher than the estimates of the European cocaine market (US\$35.6 bn dollars in $2009 .^{30}$ A study by the UNODC questioned the SOS Impresa estimates, arguing that they are "most probably gross overestimates". ${ }^{31}$ Nevertheless, the results were massively reported in the media, including the international ones. ${ }^{32}$ In particular, a particularly successful claim was that, given its liquidity, "Mafia Inc. is the first bank in Italy" 33

Despite the claim by scholars that mythical numbers have no impact on actual policies, the successful careers of the above-mentioned numbers may prove, at least partially, the contrary. For example, the numbers were used by the UN and the European Commission to call for further resources and policy actions in the fight against organized crime. Furthermore, during the campaign for the Italian 2013 parliamentary elections, some parties argued that the financial resources to redress the country's economy should be obtained by 
confiscating mafia proceeds. ${ }^{34}$ This shows that unreliable estimates can be the basis for policies which, in their turn, are likely to fail owing to the untrustworthiness of the initial assumptions.

These considerations suggest that there is a need for better and more consistent estimations of mafia proceeds in Italy. The lack of reliable methodologies is an opportunity for the creation of mythical numbers which may have a significant impact not only on the general perception in the media and public opinion but also on the policies designed to prevent and fight mafias.

\section{Methodology}

Given the vitality of unreliable figures on the mafia proceeds, this study undertakes the daunting task of developing a new, transparent and more reliable methodology with which to estimate mafia revenues. Owing to the lack of previous studies on the revenues of organized crime, the methods and the results of this study do not claim to be the final word on the subject, but rather a first, exploratory attempt whose purpose is to enable better knowledge and better analyses in the future.

This study is inspired by a research project conducted by Transcrime for the Ministry of Interior. ${ }^{35}$ One of the main tasks of Transcrime's project was to estimate the proceeds of crime deriving from a number of criminal activities in Italy. This article is based on estimates updated and revised according to most recent available data. The results are in line with those presented in Transcrime's report, with some differences due to the just mentioned updates.

The analysis of mafia proceeds presented in this article took a bottom-up approach similar to the one adopted by the above-mentioned study by Transcrime. Instead of estimating the proceeds of all criminal activities with a common methodology, it was preferred to select a number of criminal activities and markets and develop a specific 
estimation for each of them. The criminal activities were selected by applying two main criteria. The first was the frequent association in the literature and official sources of a criminal activity with the mafias. The second criterion was the availability of information and data enabling estimation of the revenues generated by each activity in a transparent, reliable and replicable way. As a result of the selection, the analysis focused on 1) sexual exploitation of women, 2) illicit firearms trafficking, 3) drug trafficking, 4) counterfeiting of goods, 5) illicit cigarette trade, 6) illicit gambling 7) illicit waste disposal, 8) loan sharking and 9) extortion racketeering. The methodology and estimates are discussed in greater detail in the previous articles of this double-special issue.

The methodology consisted in three steps:

(1) estimation of the proceeds of crime from selected criminal markets and activities;

(2) allocation of a share of the proceeds of crime to mafia proceeds;

(3) distribution of the mafia proceeds among different types of mafias.

\section{Estimation of the proceeds of crime from nine criminal activities}

The illegal revenues for each activity were estimated at both the national and regional level. Each estimation adopted different methodologies according to the specificities of the criminal market, previous evaluations in the literature, and the availability of data.

The analysis considered only the midpoint estimates for each criminal activity (Table 1). Overall, the sum of the revenues from the criminal activities selected amounted to more than $€ 22$ bn, equal to approximately $1.5 \%$ of Italian GDP (average 2007-2011) or €379 per resident (average 2007-2012). Extortion, loan sharking, sexual exploitation, counterfeiting and drugs accounted for more than $85 \%$ of the criminal revenues. 
Table 1. Proceeds of crime by criminal activity in Italy. Midpoint estimates ( $€$ bn) and shares of the total.

Year Proceeds of crime Share of total $r$

\begin{tabular}{lcrr} 
Trafficking \& sexual exploitation & 2004-05 \& 2008-09 & 3081.34 & $12.6 \%$ \\
Firearms & 2010 & 93.47 & $0.4 \%$ \\
Drugs & $2008-2012$ & 3310.70 & $13.5 \%$ \\
Counterfeiting & 2008 & 4541.27 & $18.6 \%$ \\
Gambling & 2011 & 424.56 & $1.7 \%$ \\
Waste & $2007-2010$ & 405.33 & $1.7 \%$ \\
Cigarettes & 2012 & 1139.06 & $4.7 \%$ \\
Loan Sharking & 2012 & 4634.22 & $18.9 \%$ \\
Extortion racketeering & 2012 & 5252.55 & $21.5 \%$ \\
\hline Total & & 22882.49 &
\end{tabular}

Source: author's elaboration

\section{Allocation of a share of the proceeds of crime to the mafias in general}

The analysis allocated a share of the proceeds of crime to the mafias (Mafia Proceeds). The allocation was conducted for each criminal activity and region and calculated a minimum and a maximum share. The calculation of Mafia Proceeds was based on the following formulas, where $x$ is one of the selected criminal activities:

Mafia Proceeds $\mathrm{x}_{\text {reg }_{\max }}=$ Illegal Revenues $\mathrm{x}_{\mathrm{reg}} \cdot$ Theoretical Share $\mathrm{x}_{\max } \cdot$ Effective Share ${ }_{\text {reg }}$ Mafia proceeds $\mathrm{x}_{\text {reg }_{\min }}=$ Illegal Revenues $\mathrm{x}_{\text {reg }} \cdot$ Theoretical Share $\mathrm{x}_{\min } \cdot$ Effective Share $_{\text {reg }}$ Estimation of the mafia proceeds moved through two phases.

The first phase estimated what part of each illegal activity was theoretically controllable by the mafias (Theoretical Share). Considering the exploratory nature of the analysis, it identified minimum and maximum (theoretical) shares. As far as possible, the shares were differentiated by sub-activities (e.g. for different types of drugs) on the basis of specific considerations regarding control by criminal organizations (Table 2). The main assumption was that mafias are unable to achieve monopoly at the regional level in any 
criminal activity, with the sole exception of extortion racketeering, which is considered typical of mafias. This assumption was grounded on the findings in the criminological literature on criminal markets. Criminal activities are normally undertaken by a wide array of actors, and it would be incorrect to assume that mafias control or monopolize any of them. Studies have highlighted that, with the exception of extortion racketeering, criminal activities at the national and regional level are not monopolized by mafias. The most significant example is provided by the drugs market. The literature has constantly rejected the hypothesis of monopoly and oligopoly by large structured mafias. ${ }^{36}$ These results have been confirmed also in Italy, except for some small areas, e.g. villages or city neighborhoods, where elements of mafia monopoly have been observed. ${ }^{37}$

Table 2. Minimum and maximum Theoretical Share per criminal activity.

Activities

Sexual exploitation

Firearms

Drugs

Counterfeiting

Gambling

Illegal waste trade

Illicit tobacco trade

Loan sharking

Extortion

Source: author's elaboration
Sub-activities $\quad$ Min $\max$

$20 \quad 40$

Cocaine $\quad 40 \quad 80$

Cannabis $\quad 30 \quad 50$

Amphetamines $\quad 10 \quad 30$

Ecstasy $10 \quad 30$

$10 \quad 50$

$20 \quad 80$

Non-hazardous waste $\quad 20 \quad 60$

Hazardous waste $\quad 30 \quad 80$

$20 \quad 80$

$40 \quad 80$

$100 \quad 100$

The second phase consisted in estimation of the share of each activity effectively controlled by the mafias (Effective Share). It was assumed that, although it is theoretically possible to control a given share of a criminal market, a mafia must have a strong presence to do so. Therefore the main assumption was that in regions where mafias have a stronger presence, they are effectively able to control a share of illegal activities equal to the one theoretically 
controllable. In regions where mafias have a lower presence, by contrast, they do not have the operational capacity and connections to do so, and they may actually control only a fraction of what they could.

Mafia presence was measured by means of the Mafia Presence Index (MPI) developed by Transcrime for the Italian Ministry of the Interior. ${ }^{38}$ Design of the MPI was based on previous attempts to measure the presence of mafias across Italian provinces in a reliable though efficient way. ${ }^{39}$ The index is the arithmetic mean of five normalised variables (maximum value $=1000)$ :

(1) reported mafia murders and attempted mafia murders, average of annual rates per 10,000 inhabitants, 2004-2011.

(2) people reported for mafia-type criminal association, average of annual rates per 10,000 inhabitants, 2004-2011.

(3) city councils dissolved for mafia infiltration, number of times, 2000-August 2012.

(4) assets confiscated from criminal organizations, rate per 10,000 inhabitants, 20002011.

(5) groups reported by the Direzione Investigativa Antimafia (Investigative Antimafia Directorate, DIA) and the Direzione Nazionale Antimafia (National Antimafia Directorate, DNA), average reported groups per year, $2000-2011 .^{40}$ In total, the analysis covered 24 semi-annual DIA reports (from the first half of 2000 to the second half of 2011), and 11 annual DNA reports (2000-2011). ${ }^{41}$ For each report, the study recorded individual criminal groups, the types of criminal organization, and the area in which they were present (municipality or province). ${ }^{42}$ 
Figure 1. Mafia Presence Index at the municipal, provincial and regional levels (2000-2011).
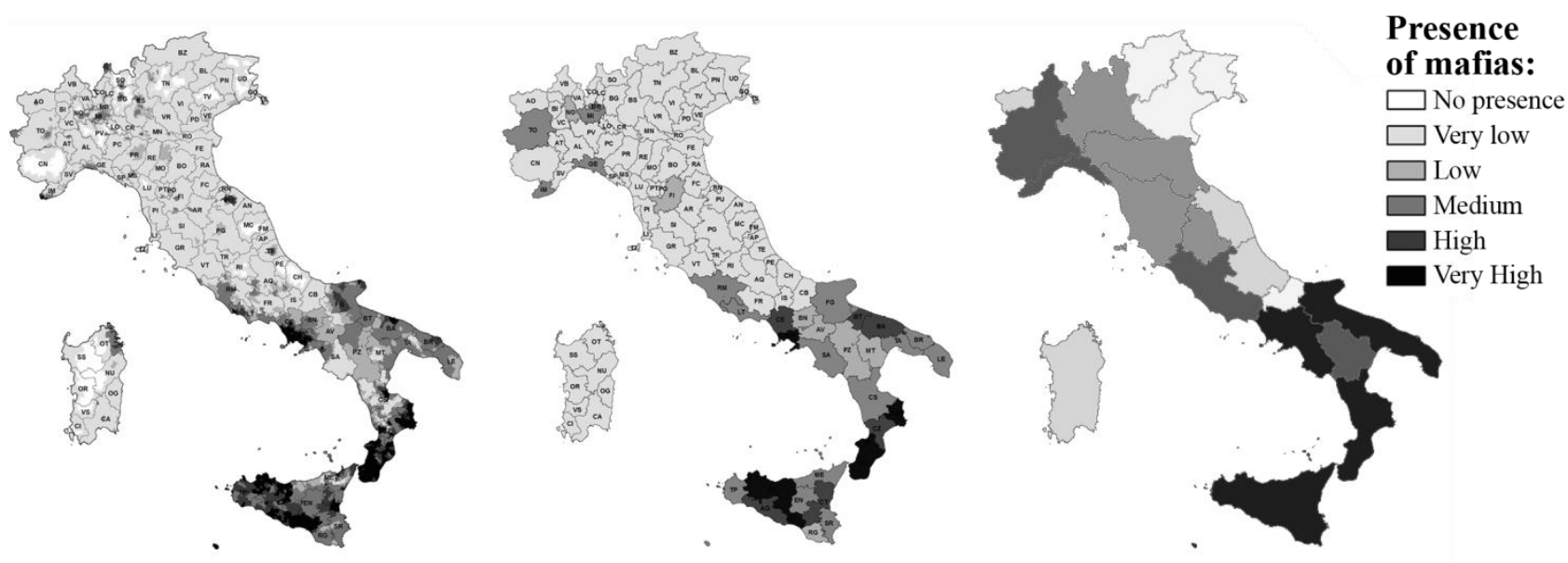

Source: author's elaboration onTranscrime data

The MPI measured the presence of mafias in Italy at the municipal level. Aggregation at the provincial and regional level provided synthetically analyzable variables (Figure 1 and Table 3). ${ }^{43}$ The regional scores of the MPI should be interpreted with caution. The strong mafia presence in a few southern regions - especially Campania, where the Camorra is traditionally characterized by numerous small groups and a very high number of mafia murders - leads to a considerable concentration of the MPI values. However, also relatively low values can indicate a significant mafia presence able to influence criminal markets, as well as the legal economy and politics. For this reason, the study divided the twenty Italian regions into quintiles. It assigned to each quintile a parameter (Effective Share) representing the share of illegal activities effectively controlled by mafias in the theoretically controllable share. Therefore, the Effective Share for the first quintile, corresponding to the regions with the highest MPI values, was $100 \%, 80 \%$ for the second, $60 \%$ for the third, $40 \%$ for the fourth, and $20 \%$ for the last quintile (Table 3). The calculation of Mafia Proceeds generated minimum and maximum values corresponding to the hypotheses of low or high mafia control of each a criminal market. 
Table 3. Mafia Presence Index and Effective Share per region

$\begin{array}{ccc}\text { Region } & \text { Mafia Presence Index } & \text { Effective Share } \\ \text { Campania } & 61.21 & 1 \\ \text { Calabria } & 41.76 & 1 \\ \text { Sicily } & 31.80 & 1 \\ \text { Apulia } & 17.84 & 1 \\ \text { Lazio } & 16.83 & 0.8 \\ \text { Liguria } & 10.44 & 0.8 \\ \text { Piedmont } & 6.11 & 0.8 \\ \text { Basilicata } & 5.32 & 0.8 \\ \text { Lombardy } & 4.17 & 0.6 \\ \text { Tuscany } & 2.16 & 0.6 \\ \text { Umbria } & 1.68 & 0.6 \\ \text { Emilia-Romagna } & 1.44 & 0.6 \\ \text { Abruzzo } & 0.74 & 0.4 \\ \text { Sardinia } & 0.70 & 0.4 \\ \text { Marche } & 0.67 & 0.4 \\ \text { Valle d'Aosta } & 0.57 & 0.4 \\ \text { Friuli Venezia Giulia } & 0.42 & 0.2 \\ \text { Veneto } & 0.41 & 0.2 \\ \text { Trentino-Alto Adige } & 0.37 & 0.2 \\ \text { Molise } & 0.31 & 0.2\end{array}$

Source: author's elaboration on Transcrime data

\section{Distribution of mafia proceeds among different types of mafias}

The analysis distributed mafia proceeds among the five main types of mafia: Cosa Nostra, Camorra, 'Ndrangheta, Apulian mafias, and other mafias. This estimation was conducted for each criminal activity, region and type of mafia. The calculations were based on the following formulas (example for the proceeds attributable to Cosa Nostra):

$$
\begin{aligned}
& \text { CN Proceeds } \mathrm{x}_{\mathrm{reg}_{\max }}=\text { Mafia Proceeds } \mathrm{x}_{\max _{\mathrm{reg}}} \cdot \% \text { Presence } \mathrm{CN}_{\text {reg }} \\
& \text { CN Proceeds } \mathrm{x}_{\mathrm{reg}_{\min }}=\text { Mafia Proceeds } \mathrm{x}_{\min _{\mathrm{reg}}} \cdot \% \text { Presence } \mathrm{CN}_{\mathrm{reg}}
\end{aligned}
$$

where $x$ is one of the selected criminal activities and Mafia Proceeds are calculated as described in the previous subsection.

Analysis of the distribution of the five types of mafia across Italian regions was based on the 
number of groups reported by the DIA and the DNA from 2000 to 2011 (variable 5 of the MPI). As displayed in Figure 2, the five types of mafia concentrate in different areas of Italy.

Figure 2. Presence of Cosa Nostra, Camorra, 'Ndrangheta, Apulian mafias and other criminal organizations in Italy (2000-2011).

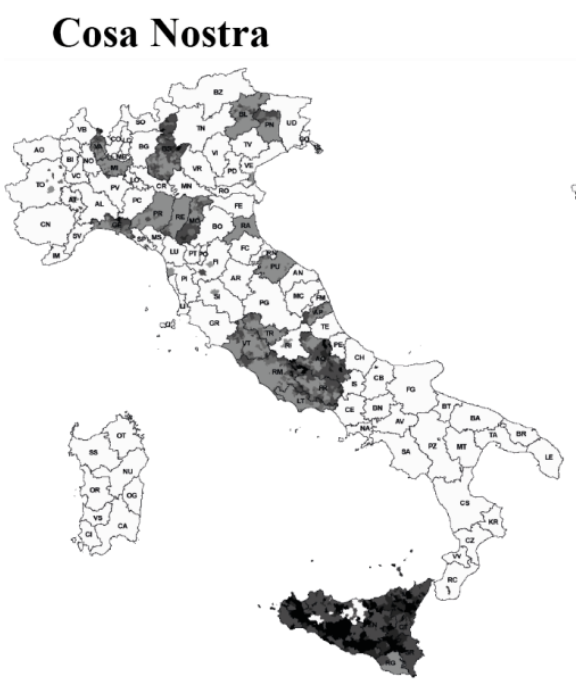

\section{Camorra}

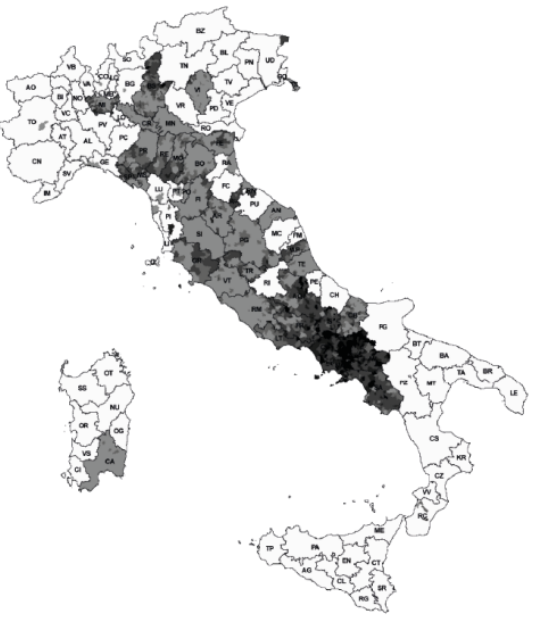

\section{Presence of mafias:}

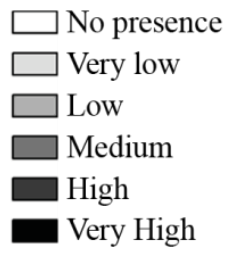

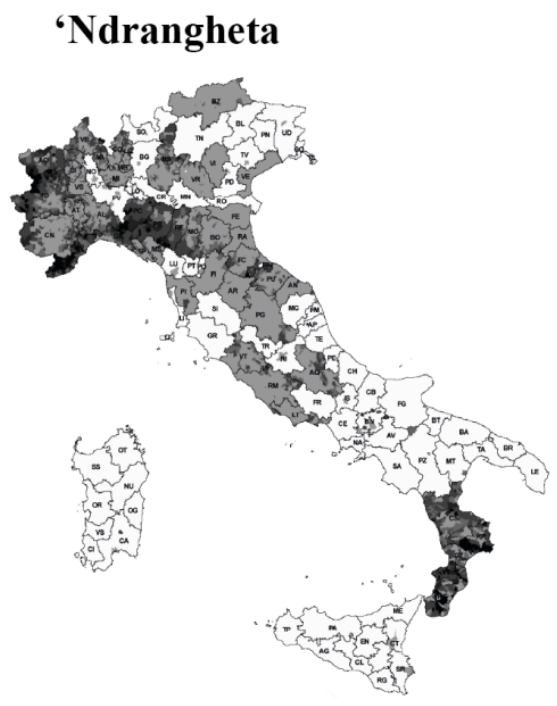

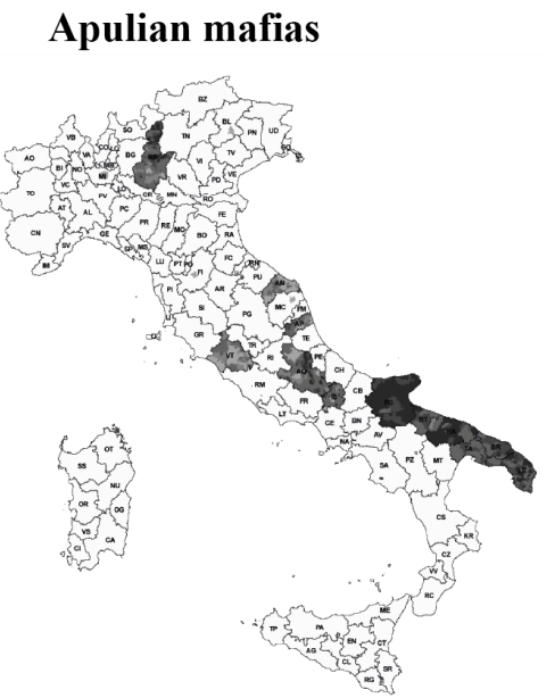

\section{Other mafias}

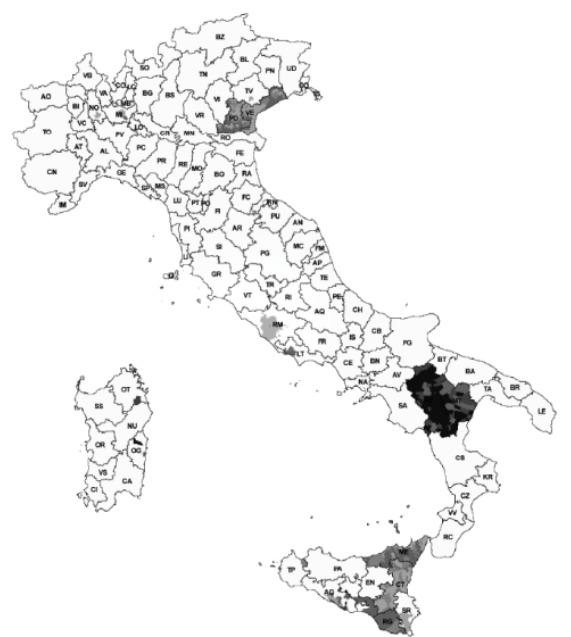

Source: author's elaboration on Transcrime data

The relative presence of each type of mafia at the municipal level was calculated as the ratio between the average number of groups of mafia type $i$ and the total number of mafia groups (\% Presence $\mathrm{CN}$ in the above formula). The resulting coefficients measured the share attributable to Cosa Nostra, Camorra, 'Ndrangheta, Apulian mafias and other mafias, 
respectively. Aggregation at the regional level (weighting each municipal ratio by the resident population 2004-2010) yielded regional scores of mafia presence by type (Table 4).

Table 4. Share of mafia presence by type of mafia and region.

\begin{tabular}{lrrrrr} 
Region & Cosa Nostra & Camorra & 'Ndrangheta & Apulian OC & Other OC \\
\hline Abruzzo & $8.9 \%$ & $80.6 \%$ & $6.1 \%$ & $4.5 \%$ & $0.0 \%$ \\
Basilicata & $0.0 \%$ & $0.0 \%$ & $0.6 \%$ & $0.0 \%$ & $99.4 \%$ \\
Calabria & $0.0 \%$ & $0.1 \%$ & $99.9 \%$ & $0.0 \%$ & $0.0 \%$ \\
Campania & $0.0 \%$ & $99.8 \%$ & $0.1 \%$ & $0.0 \%$ & $0.0 \%$ \\
Emilia R. & $8.8 \%$ & $24.4 \%$ & $66.9 \%$ & $0.0 \%$ & $0.0 \%$ \\
Friuli-V.G. & $73.9 \%$ & $24.3 \%$ & $1,8 \%$ & $0,0 \%$ & $0,0 \%$ \\
Lazio & $31,0 \%$ & $35,6 \%$ & $30,4 \%$ & $0,7 \%$ & $2,2 \%$ \\
Liguria & $22,7 \%$ & $7,0 \%$ & $70,3 \%$ & $0,0 \%$ & $0.0 \%$ \\
Lombardy & $11.6 \%$ & $29.2 \%$ & $53.1 \%$ & $5.0 \%$ & $1.1 \%$ \\
Marche & $7.0 \%$ & $21.5 \%$ & $54.8 \%$ & $16.7 \%$ & $0.0 \%$ \\
Molise & $0.2 \%$ & $93.4 \%$ & $2.7 \%$ & $3.7 \%$ & $0.0 \%$ \\
Piedmont & $2.9 \%$ & $1.1 \%$ & $95.2 \%$ & $0.0 \%$ & $0.8 \%$ \\
Apulia & $0.0 \%$ & $0.0 \%$ & $0.0 \%$ & $100.0 \%$ & $0.0 \%$ \\
Sardinia & $0.0 \%$ & $71.0 \%$ & $27.8 \%$ & $0.0 \%$ & $1.3 \%$ \\
Sicily & $91.1 \%$ & $0.0 \%$ & $0.5 \%$ & $0.0 \%$ & $8.5 \%$ \\
Tuscany & $5.9 \%$ & $57.7 \%$ & $34.9 \%$ & $1.5 \%$ & $0.0 \%$ \\
Trentino A.A. & $0.0 \%$ & $0.0 \%$ & $100.0 \%$ & $0.0 \%$ & $0.0 \%$ \\
Umbria & $5.6 \%$ & $59.1 \%$ & $35.4 \%$ & $0.0 \%$ & $0.0 \%$ \\
V. d'Aosta & $0.0 \%$ & $0.0 \%$ & $100.0 \%$ & $0.0 \%$ & $0.0 \%$ \\
Veneto & $5.4 \%$ & $12.5 \%$ & $37.3 \%$ & $0.9 \%$ & $43.9 \%$
\end{tabular}

NB: the sum of the regional shares may differ from 100 because of rounding.

Source: author's elaboration on Transcrime data

\section{Limitations}

The discussion of mythical numbers and mafias in Italy has highlighted that this field of study has been rather neglected in past years. The lack of serious studies has required development of a new, exploratory methodology which inevitably has a number of limitations. 
Estimating the proceeds of crime is a complex task which unavoidably implies assumptions and, not infrequently, simplifications. The analysis reported here used the bottom-up approach adopted in Transcrime's report for the Italian Ministry of the Interior. It selected a limited number of criminal activities according to the frequency of the association in the literature and official reports of each activity with mafias, and the availability of data. This approach entailed that the selection of the activities was crucial in defining the scope of the estimates, and the limited number of activities examined may have underestimated mafia proceeds. For example, the lack of data prevented any exploration of corruption (e.g. public contracts awarded to mafia-related enterprises in exchange for bribes or other favors), sport betting (e.g. match fixing in football championships), urban waste disposal (e.g. revenues from the illicit disposal of urban waste).

Also the allocation of a share of the proceeds of crime to mafias encountered several difficulties. First, while a number of studies reject the hypothesis that organized crime monopolizes criminal markets, there is no research on the actual "market share" of criminal organizations. This deficiency required adoption of an exploratory approach which assigned to each criminal activity a share which might theoretically be controlled by organized crime (minimum-maximum range). This process was based on various sources and assumptions (e.g. the relevance of a given criminal market for the mafias, technical and operational requirements, and the fragmentation of markets). Unfortunately, it was impossible to establish clear criteria for selection of the above-mentioned shares, and the choices adopted in this study may seem nothing more than informed guesswork. However, compared with the existing mythical numbers, the approach adopted here is more conservative, in that it rejects the idea of a mafia monopoly and identifies a range of mafia market shares. Second, the MPI may be influenced by the reliability and availability of the variables used to calculate it. A previous study in the literature has analyzed the reliability of measurement of mafia presence 
based on four out of the five variables included in the MPI. It also compared the results with another index comprising a larger number of variables, finding a very high and significant correlation. ${ }^{44}$ These findings suggest that the MPI is a reliable instrument with which to measure the mafia presence in Italy.

The distribution of criminal proceeds among the different types of mafia also has limitations. First, it is closely dependent on the data extracted by Transcrime from the reports of the DIA and DNA. The analysis may be biased by the law enforcement agencies' perceptions. Nevertheless, both the DIA and the DNA are highly specialized bodies with more than twenty years of experience in the field. Their reports provide a wealth of information and are organized into sections devoted to the different mafias and regions. Transcrime's study analyzed tens of thousands of pages recording the groups reported in each municipality and province. The measurement was consistent with the findings in the literature, the media, and other official accounts (Figure 2). In the absence of any better analysis, the breakdown provided by Transcrime appears to be the most reliable proxy of the presence of the various mafias. A second limitation was that it was not possible to differentiate among different types of mafias, and the study assumed that all of them may have the same prevalence in a given criminal market. This was due to a lack of evidence which prevented the drawing of any reliable distinctions.

The above considerations recommend caution in interpreting the result of this study. The aim of the analysis is not to pass final judgment on the topic of mafia proceeds, but rather to explore possible estimation methods taking account of the main results in the literature. The findings should be considered as those of a first attempt to quantify the revenues of the mafias in Italy using a replicable and clearly described methodology. They may provide the basis for future studies using more refined approaches, which will most likely depend on the availability of better data. 


\section{Results and discussion}

\section{Mafia proceeds}

Table 5 reports the yearly estimates of mafia proceeds by activity and region. At national level, the revenues of the mafias from the criminal activities selected range between a minimum of $€ 8.4$ bn to a maximum of $€ 13 \mathrm{bn}$. Compared with the total illegal revenues (midpoint estimate $€ 22.8 \mathrm{bn}$ ), those attributable to the mafias may vary between $37 \%$ and $57 \%$. They represent between $0.6 \%$ and $0.9 \%$ of GDP and between $€ 141$ and $€ 218$ per resident. Since the criminal activities considered are only a selection of the sources of revenues for mafias, their magnitude compared with the national economy is significant.

Extortion racketeering is the main source of mafia revenues, yielding more than $€ 5.2$ bn, equal to $49 \%$ of the total amount (considering the midpoint estimate between the minimum and maximum values). It is followed by loan sharking (20\%) and drugs (11\%) and counterfeiting (8\%) (Figure 3).

These results suggest that closer attention should be paid to extortion racketeering and usury, particularly considering the widespread idea that mafias derive most of their incomes from drugs. These findings receive some support in the literature. One theoretical approach to mafias treats them as suppliers of private protection, an activity where they can exploit their specialization in the use of violence. ${ }^{45}$ While extortion and private protection are different, though sometimes overlapping, concepts, the focus on these activities highlights their key function for mafias instead of other criminal markets, e.g. drug trafficking. ${ }^{46}$ Other scholars have demonstrated that criminal markets are not particularly suited to large structured groups like mafias. ${ }^{47}$ The frequent assumptions that a) criminal markets are monopolized by mafias, and that $b$ ) the provision of illicit goods and services is their main activity, have been shown to be paradoxes rather than empirically-based facts. ${ }^{48}$ While in line with the literature, the particular role of extortion racketeering was one of the main assumptions of the analysis 
(which attributed $100 \%$ of the estimated revenues to mafias) and this inevitably affected its share in total mafia proceeds. Yet the estimated revenues are higher than those deriving from any other of the selected activities. Differently from the Transcrime report, the update of the estimates resulted in extortion revenues higher than those from drugs because of the different years considered (drug consumption may have declined due to economic difficulties) and estimation methodologies used.

Closer attention to extortion racketeering may have significant implications. Indeed, it may partially contribute to explaining the differences in economic performance between Italy and other developed countries. While all the latter record high levels of drug consumption, only Italy has a strong mafia presence on its territory. A number of studies have shown that the mafia impacts on various elements of economic performance, from the general economic structure $^{49}$ to regional GDP growth ${ }^{50}$, firms' productivity, ${ }^{51}$ and foreign direct investments. ${ }^{52}$ All these effects may be associated with the mafias' extortion racketeering, which is likely to affect the local and national economy more than criminal markets like drug trafficking.

Loan sharking may share some of the considerations that apply to extortion racketeering. Violence, threats, and intimidation are important assets for success in the usury market. While some criminal entrepreneurs may resort to external enforcers, mafias have a reputation which may effectively facilitate the in-house recovery of credit in the case of need. A number of investigations have shown that mafias may use loan sharking as a means to gain control of enterprises and shops with mechanisms that closely resemble extortion racketeering. ${ }^{53}$ 
Figure 3. Share of mafia proceeds by criminal activity. Average estimates.

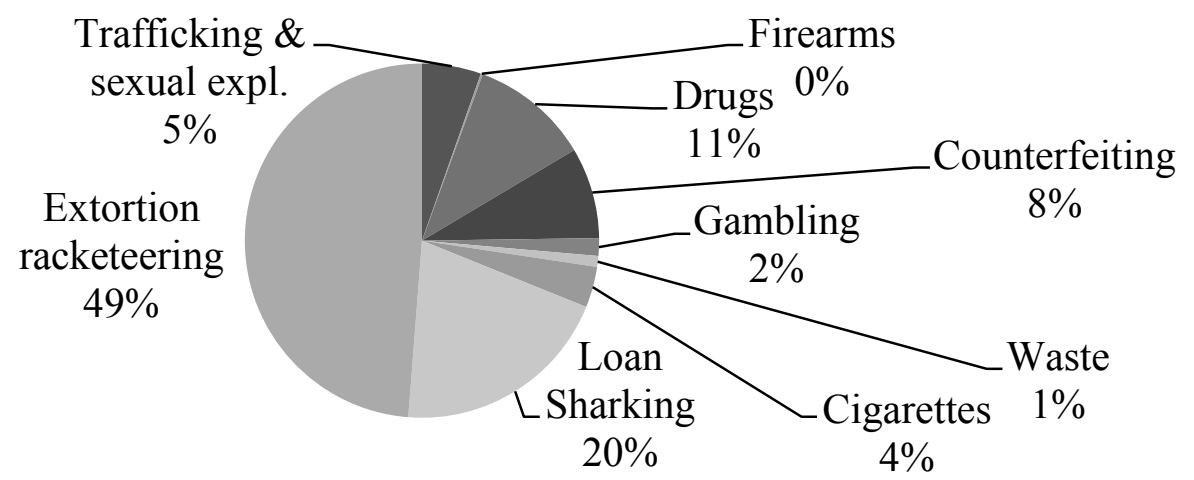

Source: author's elaboration 
Table 5. Mafia proceeds by activity and region. Minimum and maximum estimates $(€ \mathrm{mn})$.

\begin{tabular}{|c|c|c|c|c|c|c|c|c|c|c|c|}
\hline Region & & $\begin{array}{c}\text { Traff. \& } \\
\text { sexual ex. }\end{array}$ & Firearms & Drugs & $\begin{array}{c}\text { Counterfeit } \\
\text { ing }\end{array}$ & Gambling & Waste & Cigarettes & $\begin{array}{c}\text { Loan } \\
\text { Sharking }\end{array}$ & $\begin{array}{c}\text { Extortion } \\
\text { racket }\end{array}$ & Total \\
\hline Abruzzo & $\max$ & 13.65 & 0.28 & 18.09 & 19.78 & 0.83 & 1.89 & 8.31 & 49.48 & 58.14 & 170.46 \\
\hline Basilicata & $\min$ & 5.75 & 0.22 & 6.70 & 2.67 & 1.38 & 0.58 & 0.79 & 25.16 & 23.87 & 67.13 \\
\hline \multirow{2}{*}{ Calabria } & $\min$ & 8.72 & 1.04 & 30.92 & 11.96 & 5.50 & 1.27 & 2.63 & 114.48 & 626.46 & 802.97 \\
\hline & $\max$ & 17.44 & 2.07 & 61.48 & 59.78 & 21.99 & 3.79 & 10.52 & 228.97 & 626.46 & $1,032.49$ \\
\hline Campania & $\min$ & 28.64 & 2.22 & 137.47 & 42.54 & 12.23 & 4.71 & 65.18 & 324.85 & $1,538.90$ & $2,156.73$ \\
\hline $\begin{array}{l}\text { Emilia- } \\
\text { Romagna }\end{array}$ & $\max$ & 35.28 & 1.14 & 97.15 & 111.84 & 2.75 & 10.96 & 24.40 & 64.42 & 131.58 & 479.52 \\
\hline \multirow{2}{*}{ Friuli-V.G. } & $\min$ & 6.84 & 0.07 & 3.11 & 2.43 & 0.34 & 0.44 & 2.32 & 4.01 & 40.97 & 60.52 \\
\hline & $\max$ & 13.67 & 0.14 & 6.14 & 12.14 & 1.37 & 1.30 & 9.27 & 8.02 & 40.97 & 93.02 \\
\hline \multirow{2}{*}{ Lazio } & $\min$ & 83.35 & 1.23 & 70.87 & 34.74 & 4.58 & 5.47 & 10.41 & 145.04 & 208.55 & 564.24 \\
\hline & $\max$ & 166.70 & 2.46 & 141.35 & 173.71 & 18.32 & 16.31 & 41.63 & 290.08 & 208.55 & $1,059.10$ \\
\hline Liguria & $\min$ & 24.37 & 0.59 & 37.30 & 9.91 & 0.08 & 1.44 & 2.13 & 41.82 & 59.16 & 176.79 \\
\hline Marche & $\max$ & 17.85 & 0.32 & 21.10 & 20.57 & 0.89 & 4.01 & 5.84 & 39.39 & 111.60 & 221.57 \\
\hline \multirow{2}{*}{ Molise } & $\min$ & 0.66 & 0.03 & 1.34 & 0.38 & 0.03 & 0.13 & 0.16 & 3.36 & 17.86 & 23.93 \\
\hline & $\max$ & 1.32 & 0.05 & 2.66 & 1.88 & 0.10 & 0.38 & 0.64 & 6.72 & 17.86 & 31.61 \\
\hline \multirow{2}{*}{ Piedmont } & $\min$ & 38.35 & 0.81 & 76.29 & 23.67 & 9.33 & 3.85 & 10.30 & 95.98 & 252.64 & 511.21 \\
\hline & $\max$ & 76.70 & 1.61 & 150.94 & 118.34 & 37.30 & 11.36 & 41.20 & 191.96 & 252.64 & 882.05 \\
\hline \multirow{2}{*}{ Apulia } & $\min$ & 20.41 & 2.00 & 65.41 & 25.68 & 10.55 & 6.73 & 7.04 & 193.37 & 516.67 & 847.87 \\
\hline & $\max$ & 40.82 & 4.00 & 129.99 & 128.41 & 42.21 & 20.12 & 28.16 & 386.74 & 516.67 & $1,297.12$ \\
\hline \multirow{2}{*}{ Sardinia } & $\min$ & 2.67 & 0.17 & 17.81 & 4.04 & 4.13 & 1.24 & 2.18 & 29.28 & 35.41 & 96.93 \\
\hline & $\max$ & 5.35 & 0.33 & 35.47 & 20.19 & 16.53 & 3.69 & 8.70 & 58.56 & 35.41 & 184.24 \\
\hline \multirow{2}{*}{ Sicily } & $\min$ & 25.31 & 1.49 & 66.85 & 30.76 & 16.68 & 6.69 & 14.58 & 214.74 & 756.66 & $1,133.75$ \\
\hline & $\max$ & 50.62 & 2.98 & 132.87 & 153.78 & 66.71 & 19.16 & 58.34 & 429.48 & 756.66 & $1,670.60$ \\
\hline
\end{tabular}




\begin{tabular}{|c|c|c|c|c|c|c|c|c|c|c|c|}
\hline \multirow{2}{*}{ Tuscany } & $\min$ & 19.95 & 0.99 & 37.73 & 17.03 & 1.01 & 6.15 & 6.14 & 54.97 & 218.41 & 362.38 \\
\hline & $\max$ & 39.91 & 1.98 & 74.47 & 85.15 & 4.03 & 18.37 & 24.57 & 109.94 & 218.41 & 576.82 \\
\hline $\begin{array}{c}\text { Trentino- } \\
\text { Alto Adige }\end{array}$ & $\max$ & 7.73 & 0.08 & 7.52 & 7.94 & 0.06 & 1.34 & 2.36 & 0.03 & 39.85 & 66.90 \\
\hline Umbria & $\max$ & 32.33 & 0.77 & 16.33 & 18.15 & 0.90 & 4.08 & 4.79 & 33.09 & 26.20 & 136.64 \\
\hline \multirow{2}{*}{$\begin{array}{c}\text { Valle } \\
\text { d'Aosta }\end{array}$} & $\min$ & 0.97 & 0.01 & 1.56 & 0.32 & 0.12 & 0.06 & 0.11 & 1.18 & 13.68 & 18.01 \\
\hline & $\max$ & 1.94 & 0.01 & 3.12 & 1.60 & 0.50 & 0.17 & 0.43 & 2.37 & 13.68 & 23.82 \\
\hline \multirow{3}{*}{ Total Italy } & $\min$ & 387.41 & 13.38 & 783.38 & 298.57 & 69.44 & 54.31 & 160.76 & $1,445.27$ & $5,252.55$ & $8,465.05$ \\
\hline & $\max$ & 774.82 & 26.76 & $1,559.48$ & $1,492.85$ & 277.75 & 160.63 & 643.04 & $2,890.54$ & $5,252.55$ & $13,078.41$ \\
\hline & avg & 581.12 & 20.07 & $1,171.43$ & 895.71 & 173.59 & 107.47 & 401.90 & $2,167.90$ & $5,252.55$ & $10,771.73$ \\
\hline
\end{tabular}

Source: author's elaboration 
At the regional level, the regions of origin of the mafias account for $55 \%$ of the mafia proceeds in Italy (Figure 4 and Figure 6). Campania records the highest mafia revenues (average $€ 2.6$ bn), followed by Sicily, Apulia and Calabria (€1.4 bn, $€ 1$ bn and $€ 0.9$ bn respectively). Lazio, Lombardy and Piedmont (in the Centre and North-West of Italy) also have high values (22\%). Besides the methodological assumptions already discussed, possible explanations for these high levels may relate to the large populations of the three regions and the presence in them of the three big cities of Rome, Milan and Turin. Mafia proceeds from some of the richest and most developed regions in Italy represent an important share of the total, which further confirms that the mafias should be considered a national issue rather than a Southern peculiarity.

Figure 4. Mafia proceeds by region (absolute values, €mn). Average (point), minimum and maximum estimates (error bars).

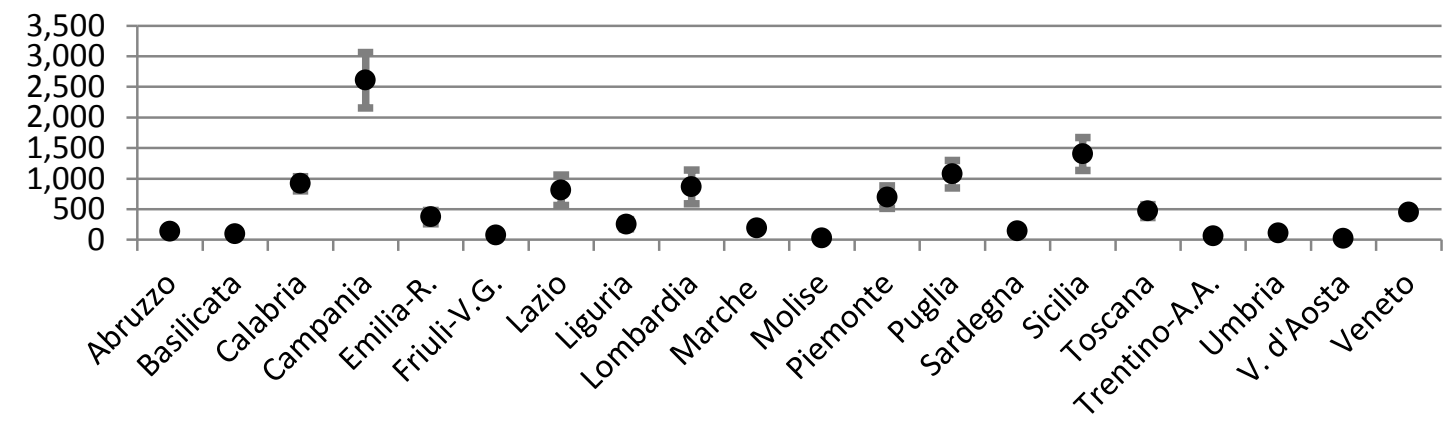

Source: author's elaboration

The critical impact of the mafias on the economies of the four regions of origin emerges when the values are normalized for the regional GDP (average 2007-2011) (Figure 5). Mafia revenues are equal to nearly 3\% of the regional GDP in Calabria and Campania, $1.7 \%$ in Sicily, and $1.5 \%$ in Apulia. Other regions do not even come close to these figures. These results demonstrate that a strong mafia presence may generate proceeds equal to a substantial share of the regional economy. Given the limited number of activities selected, the figures are probably underestimations. Nevertheless, at these 
levels, the mafias can easily influence the social, economic and political dynamics of the regions in which they operate. As already discussed, these considerations receive support from studies that have analyzed the negative impact of mafias across the Italian regions. ${ }^{54}$

Figure 5. Mafia proceeds as a share of regional GDP (average 2007-2011). Average (point), minimum and maximum estimates (error bars).

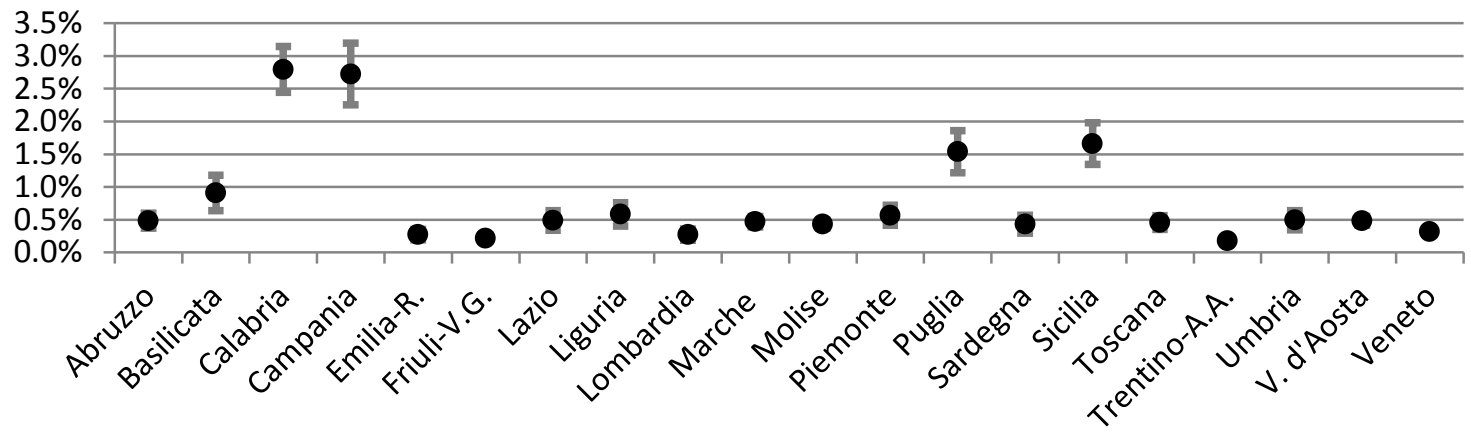

Source: author's elaboration

The regional share of mafia revenues in total illegal revenues varies (Table 6 and Figure 6). Regions with a traditional mafia presence record a share of mafia revenues amounting to between $50 \%$ and $80 \%$. Only in four other regions (Basilicata, Lazio, Liguria and Piedmont) do the maximum mafia revenues equal or slightly exceed $50 \%$. In all other regions, mafia revenues represent less than half of total illegal revenues, indicating that illegal activities are mostly undertaken by people not linked to mafias. Once again, although influenced by the methodological assumptions already discussed, the findings reveal a concentration of mafia activities in a relatively small number of regions, although not exclusively in the South. 
Table 6. Mafia proceeds by region. Absolute values $(€ \mathrm{mn})$ and shares of average illegal revenues (minimum, maximum and average estimates).

\begin{tabular}{lrrrrrr} 
& \multicolumn{3}{c}{ Absolute values } & \multicolumn{3}{c}{ Shares of illegal revenues } \\
& min & max & avg & min & max & avg \\
\cline { 2 - 6 } Abruzzo & 105.9 & 170.5 & 138.2 & $21 \%$ & $34 \%$ & $28 \%$ \\
Basilicata & 67.1 & 123.1 & 95.1 & $31 \%$ & $58 \%$ & $44 \%$ \\
Calabria & 803.0 & $1,032.5$ & 917.7 & $66 \%$ & $85 \%$ & $76 \%$ \\
Campania & $2,156.7$ & $3,060.3$ & $2,608.5$ & $58 \%$ & $82 \%$ & $70 \%$ \\
Emilia R. & 263.7 & 479.5 & 371.6 & $24 \%$ & $43 \%$ & $33 \%$ \\
Friuli V.G. & 60.5 & 93.0 & 76.8 & $12 \%$ & $18 \%$ & $15 \%$ \\
Lazio & 564.2 & $1,059.1$ & 811.7 & $28 \%$ & $53 \%$ & $40 \%$ \\
Liguria & 176.8 & 329.5 & 253.2 & $28 \%$ & $53 \%$ & $41 \%$ \\
Lombardy & 589.0 & $1,137.8$ & 863.4 & $21 \%$ & $41 \%$ & $31 \%$ \\
Marche & 158.2 & 221.6 & 189.9 & $28 \%$ & $39 \%$ & $34 \%$ \\
Molise & 23.9 & 31.6 & 27.8 & $19 \%$ & $26 \%$ & $23 \%$ \\
Piedmont & 511.2 & 882.1 & 696.6 & $34 \%$ & $58 \%$ & $46 \%$ \\
Apulia & 847.9 & $1,297.1$ & $1,072.5$ & $51 \%$ & $77 \%$ & $64 \%$ \\
Sardinia & 96.9 & 184.2 & 140.6 & $17 \%$ & $32 \%$ & $24 \%$ \\
Sicily & $1,133.8$ & $1,670.6$ & $1,402.2$ & $54 \%$ & $79 \%$ & $66 \%$ \\
Tuscany & 362.4 & 576.8 & 469.6 & $30 \%$ & $48 \%$ & $39 \%$ \\
Trentino A.A. & 50.2 & 66.9 & 58.5 & $17 \%$ & $23 \%$ & $20 \%$ \\
Umbria & 74.0 & 136.6 & 105.3 & $21 \%$ & $38 \%$ & $30 \%$ \\
V. d'Aosta & 18.0 & 23.8 & 20.9 & $32 \%$ & $43 \%$ & $37 \%$ \\
Veneto & 401.6 & 501.6 & 451.6 & $24 \%$ & $29 \%$ & $26 \%$ \\
\hline TOTAL & $8,465.05$ & $13,078.41$ & $10,771.73$ & $37 \%$ & $57 \%$ & $47 \%$ \\
Source: author's & elaboration & & & & &
\end{tabular}


Figure 6. Mafia and non-mafia proceeds by region. Average estimates (pie size=total criminal revenues from selected activities, $€ \mathrm{mn})$.

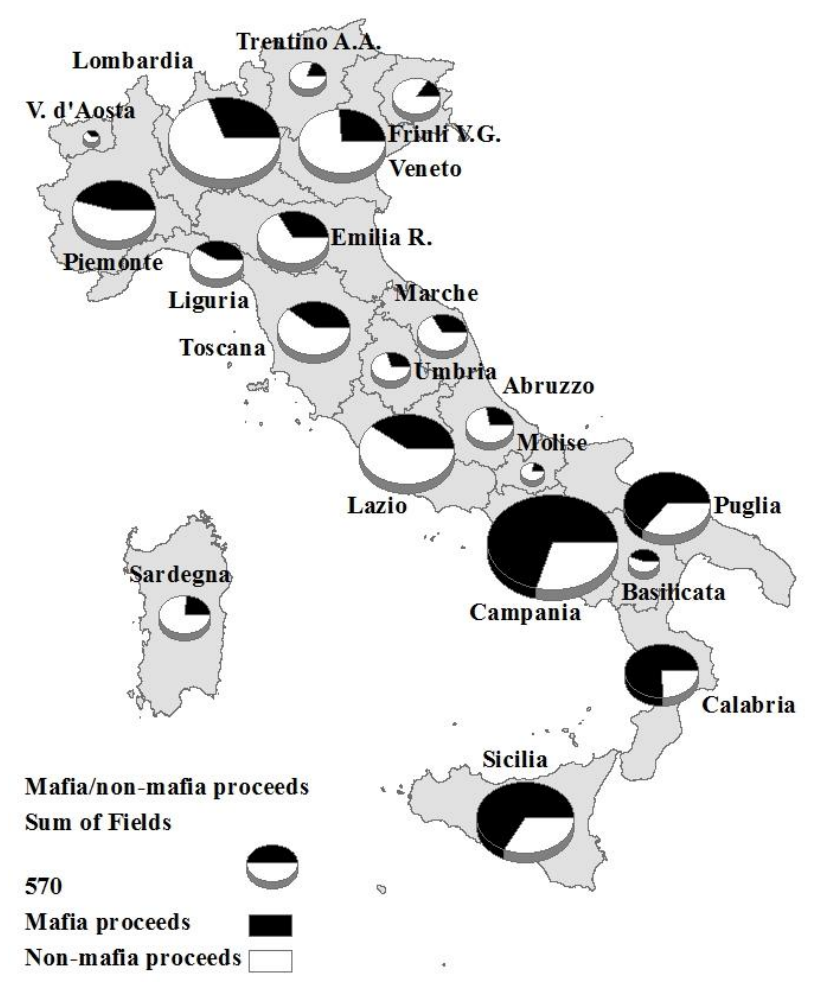

Source: author's elaboration

\section{Proceeds per type of mafia}

The allocation of the proceeds among the different types of mafias provides further information on the sources of income for Italian organized crime groups (Table 7). Overall, Camorra and 'Ndrangheta earn approximately $68 \%$ of total mafia revenues

(Figure 7). The Camorra earns between a minimum of $€ 3.1$ bn and a maximum of $€ 4.7$ bn, and the 'Ndrangheta between $€ 2.5$ and $€ 4 \mathrm{bn}$. Cosa Nostra follows, with revenues between $€ 1.4$ and $€ 2.3$ bn. The revenues of Apulian mafias vary between $€ 0.9$ and $€ 1.4$ bn. 
Figure 7. Share of mafia proceeds by type of mafia. Average estimates.

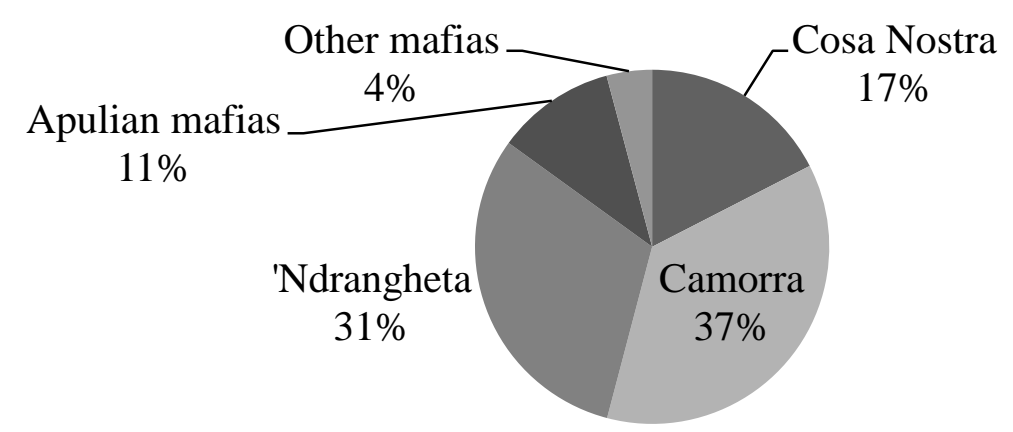

Source: author's elaboration 
Table 7. Mafia proceeds by region and type of mafia $(€ \mathrm{mn})$. Minimum and maximum estimates.

\begin{tabular}{|c|c|c|c|c|c|c|c|}
\hline Region & & Cosa Nostra & Camorra & 'Ndrangheta & $\begin{array}{c}\text { Apulian } \\
\text { mafias }\end{array}$ & $\begin{array}{c}\text { Other } \\
\text { mafias }\end{array}$ & Total \\
\hline \multirow{2}{*}{ Abruzzo } & $\min$ & 9.45 & 85.30 & 6.41 & 4.72 & 0.00 & 105.88 \\
\hline & $\max$ & 15.21 & 137.32 & 10.32 & 7.61 & 0.00 & 170.46 \\
\hline \multirow{2}{*}{ Basilicata } & $\min$ & 0.00 & 0.00 & 0.38 & 0.00 & 66.75 & 67.13 \\
\hline & $\max$ & 0.00 & 0.00 & 0.69 & 0.00 & 122.44 & 123.13 \\
\hline \multirow{2}{*}{ Calabria } & $\min$ & 0.05 & 1.13 & 801.79 & 0.00 & 0.00 & 802.97 \\
\hline & $\max$ & 0.07 & 1.46 & $1,030.97$ & 0.00 & 0.00 & $1,032.49$ \\
\hline \multirow{2}{*}{$\begin{array}{l}\text { Campani } \\
\text { a }\end{array}$} & $\min$ & 0.39 & $2,152.39$ & 3.12 & 0.77 & 0.05 & $2,156.73$ \\
\hline & $\max$ & 0.55 & $3,054.16$ & 4.43 & 1.09 & 0.08 & $3,060.31$ \\
\hline \multirow{2}{*}{$\begin{array}{l}\text { Emilia- } \\
\text { Romagna }\end{array}$} & $\min$ & 23.10 & 64.23 & 176.40 & 0.00 & 0.00 & 263.73 \\
\hline & $\max$ & 42.01 & 116.79 & 320.72 & 0.00 & 0.00 & 479.52 \\
\hline \multirow{2}{*}{$\begin{array}{l}\text { Friuli- } \\
\text { V.G. }\end{array}$} & $\min$ & 44.72 & 14.69 & 1.11 & 0.00 & 0.00 & 60.52 \\
\hline & $\max$ & 68.74 & 22.57 & 1.71 & 0.00 & 0.00 & 93.02 \\
\hline \multirow{2}{*}{ Lazio } & $\min$ & 175.02 & 201.01 & 171.74 & 3.96 & 12.50 & 564.24 \\
\hline & $\max$ & 328.53 & 377.32 & 322.36 & 7.44 & 23.46 & $1,059.10$ \\
\hline \multirow{2}{*}{ Liguria } & $\min$ & 40.13 & 12.40 & 124.26 & 0.00 & 0.00 & 176.79 \\
\hline & $\max$ & 74.80 & 23.12 & 231.61 & 0.00 & 0.00 & 329.52 \\
\hline \multirow{2}{*}{ Lombardy } & $\min$ & 68.60 & 171.76 & 312.96 & 29.36 & 6.27 & 588.96 \\
\hline & $\max$ & 132.54 & 331.84 & 604.63 & 56.72 & 12.11 & $1,137.84$ \\
\hline \multirow{2}{*}{ Marche } & $\min$ & 11.05 & 33.99 & 86.79 & 26.42 & 0.00 & 158.24 \\
\hline & $\max$ & 15.48 & 47.59 & 121.52 & 36.99 & 0.00 & 221.57 \\
\hline \multirow{2}{*}{ Molise } & $\min$ & 0.06 & 22.34 & 0.64 & 0.89 & 0.00 & 23.93 \\
\hline & $\max$ & 0.08 & 29.51 & 0.85 & 1.18 & 0.00 & 31.61 \\
\hline \multirow{2}{*}{ Piedmont } & $\min$ & 14.65 & 5.41 & 486.89 & 0.00 & 4.26 & 511.21 \\
\hline & $\max$ & 25.27 & 9.34 & 840.09 & 0.00 & 7.35 & 882.05 \\
\hline \multirow{2}{*}{ Apulia } & $\min$ & 0.00 & 0.00 & 0.00 & 847.87 & 0.00 & 847.87 \\
\hline & $\max$ & 0.00 & 0.00 & 0.00 & $1,297.12$ & 0.00 & $1,297.12$ \\
\hline \multirow{2}{*}{ Sardinia } & $\min$ & 0.00 & 68.80 & 26.91 & 0.00 & 1.23 & 96.93 \\
\hline & $\max$ & 0.00 & 130.76 & 51.14 & 0.00 & 2.34 & 184.24 \\
\hline \multirow{2}{*}{ Sicily } & $\min$ & $1,032.42$ & 0.00 & 5.33 & 0.00 & 96.00 & $1,133.75$ \\
\hline & $\max$ & $1,521.28$ & 0.00 & 7.86 & 0.00 & 141.46 & $1,670.60$ \\
\hline Tuscany & $\min$ & 21.29 & 208.99 & 126.64 & 5.46 & 0.00 & 362.38 \\
\hline
\end{tabular}




\begin{tabular}{lcrrrrrr} 
& $\max$ & 33.89 & 332.66 & 201.58 & 8.69 & 0.00 & 576.82 \\
\hline Trentino- & $\min$ & 0.00 & 0.00 & 50.19 & 0.00 & 0.00 & 50.19 \\
Alto Adige & $\max$ & 0.00 & 0.00 & 66.90 & 0.00 & 0.00 & 66.90 \\
\hline \multirow{2}{*}{ Umbria } & $\min$ & 4.12 & 43.70 & 26.18 & 0.00 & 0.00 & 74.00 \\
& $\max$ & 7.61 & 80.69 & 48.34 & 0.00 & 0.00 & 136.64 \\
\hline \multirow{2}{*}{ Valle } & $\min$ & 0.00 & 0.00 & 18.01 & 0.00 & 0.00 & 18.01 \\
d'Aosta & $\max$ & 0.00 & 0.00 & 23.82 & 0.00 & 0.00 & 23.82 \\
\hline \multirow{2}{*}{ Veneto } & $\min$ & 21.56 & 50.30 & 149.85 & 3.49 & 176.39 & 401.59 \\
& $\max$ & 26.93 & 62.83 & 187.18 & 4.35 & 220.34 & 501.64 \\
\hline \multirow{2}{*}{ Total } & $\min$ & $1,466.63$ & $3,136.45$ & $2,575.59$ & 922.93 & 363.46 & $8,465.05$ \\
Italy & $\max$ & $2,292.99$ & $4,757.95$ & $4,076.72$ & $1,421.18$ & 529.57 & $13,078.41$ \\
& $\operatorname{avg}$ & $1,879.81$ & $3,947.20$ & $3,326.15$ & $1,172.06$ & 446.52 & $10,771.73$
\end{tabular}

Source: author's elaboration

These findings suggest that Cosa Nostra has faced difficulties in recent years due to strong government action since the beginning of the 1990s. ${ }^{55}$ Moreover, the majority of Cosa Nostra's revenues come from its native Sicily (approximately 68\%, Figure 8).

Both the Camorra and the 'Ndrangheta outmatch the revenues of the Sicilian Mafia. While the raw figures for the two types of mafia are similar, there are significant differences in the structure of the organizations and the geographical distribution of their sources of revenue. The Camorra has been traditionally a constellation of different clans and groups, with a prevalently horizontal organization. With the exception of a few specific periods and groups (e.g. the Casalesi group as described in Gomorrah by Saviano), ${ }^{56}$ there have been no successful attempts to centralize or coordinate the various groups. ${ }^{57}$ The high rates of mafia murders in Naples confirm that violent conflicts among these syndicates are frequent. The Camorra groups derive most of their revenues from Campania (66\%, Figure 8), their region of origin, and particularly from the provinces of Naples and Caserta (Casalesi territory). These findings may indicate that the constantly battling Camorra groups impose an extremely heavy burden on Campania both in terms of violence and insecurity and in terms of criminal revenues. Camorra's concentration in the region may explain the latter's economic difficulties despite the availability of fertile land, an infrastructure endowment above the Italian 
average, a large city like Naples, and several cultural and natural attractions.

The case of the 'Ndrangheta is different. This mafia obtains only $28 \%$ of its revenues from Calabria, which is a low-populated and relatively underdeveloped region. The 'Ndrangheta has a more composite structure, which has possibly favoured its expansion into other Italian regions and abroad. ${ }^{58}$ As shown in 
Figure 9, Calabria furnishes only $28 \%$ of the 'Ndrangheta's proceeds. Northern Piedmont and Lombardy provide $20 \%$ and $14 \%$, respectively. Emilia-Romagna and Lazio follow with 7\% each. The 'Ndrangheta's diversified sources of income highlight its capacity to operate outside its original territory, since almost $50 \%$ of its revenues derive from four north-western regions (Lombardy, Piedmont, Emilia-Romagna and Liguria).

Figure 8 . Share of mafia proceeds from the region of origin, by type of mafia. Average estimates.

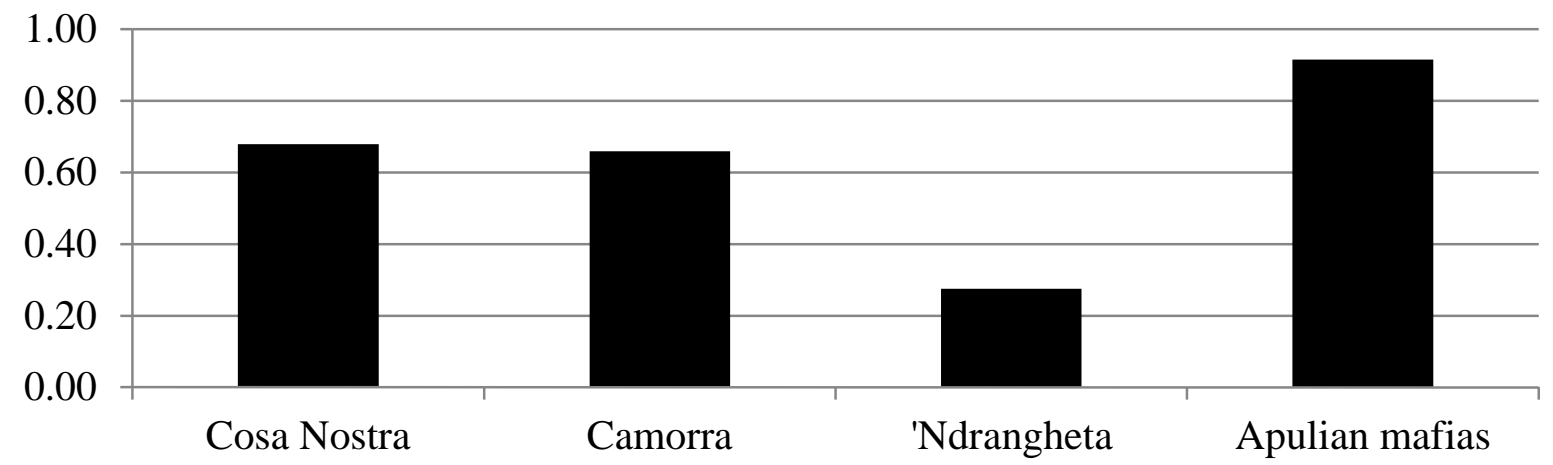

Source: author's elaboration 
Figure 9. 'Ndrangheta's proceeds by region. Shares of the total and absolute values $(€ m n)$. Average estimates.
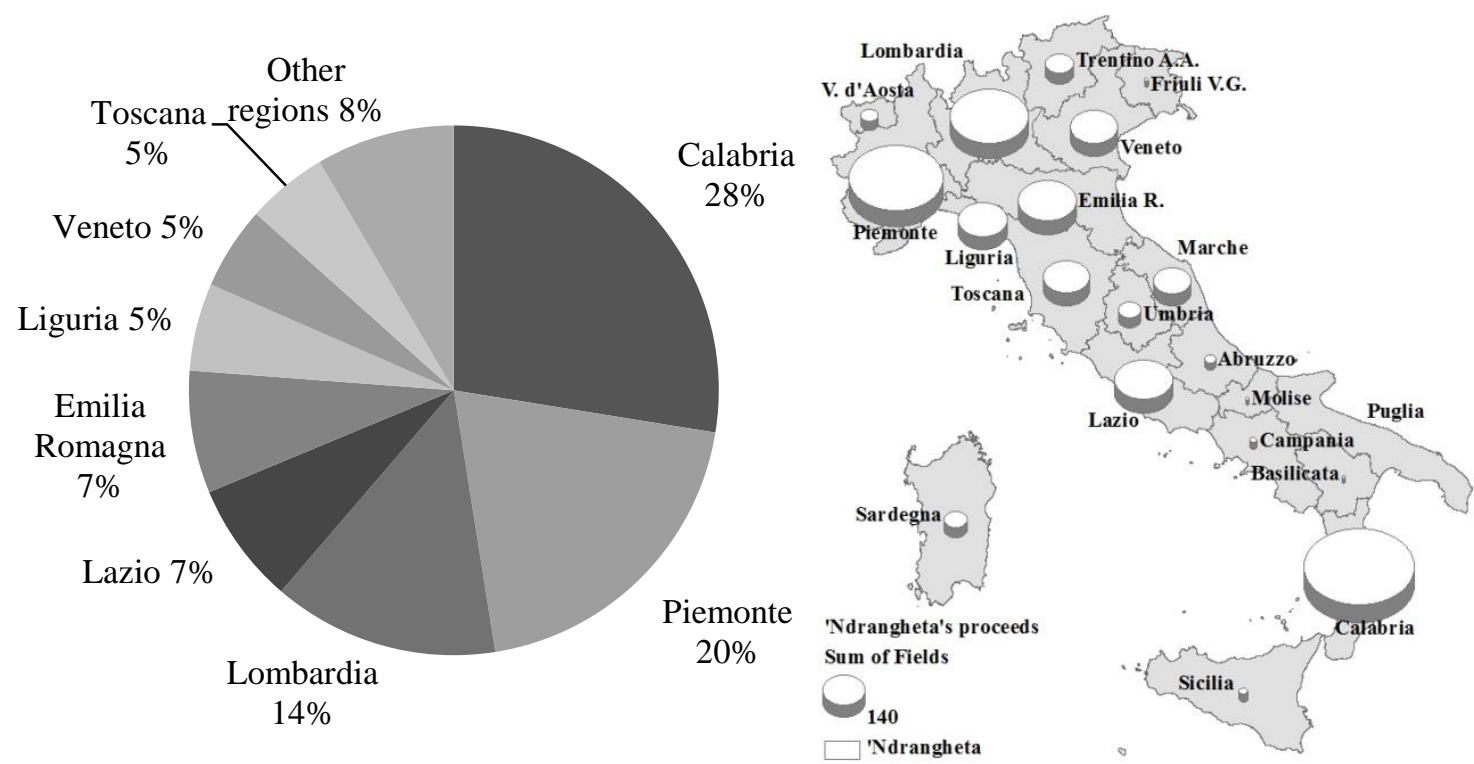

Source: author's elaboration

\section{Conclusions}

This study is a first attempt to estimate mafia proceeds in Italy. It estimates the total revenues by the mafia between $€ 8.4$ bn and $€ 13$ bn, numbers which are well below the most popular mythical numbers of $€ 150$ bn and $€ 138$ bn, widely publicized in the media and public opinion, but based on unclear or imprecise assumptions. Given the lack of previous reliable analyses, the findings reported here must be interpreted with caution. Their purpose is to stimulate public and academic debate on the actual size of mafiarelated criminal activities and their impact on the national and local economy.

This study may also prompt further reflection by academics on the persistence of mythical numbers in criminology, particularly in the field of organized crime. These figures have probably also been successful because academics have either belittled estimates or uncritically exploited their sensationalist capacity. Given the shortage of reliable data, scholars have largely refrained from producing estimates. Sometimes, instead of questioning their reliability - with the risk of long technical debates and 
damage to relations with stakeholders and funders - they have preferred to repeat these figures while citing their sources. As a result, mythical numbers on organized crime have gained power, and governments, international organizations, NGOs, and other stakeholders been provided with an effective opportunity to support their own agendas. Academics should reverse this attitude, since there is a need for more studies on the revenues of organized crime so that more precise estimations and improved policies can be produced on the phenomenon.

In their essays on mythical numbers, both Singer and Reuter expressed pessimism about the possibility of solving the problem. They probably had good reasons for doing so. Indeed, when the results of the study conducted by Transcrime were disseminated, the media and other interested stakeholders were surprised at "how low" the estimates of mafia proceeds were. However after some discussion and clarification, it was generally recognized that previous estimates were unrealistic and unreliable ("mafias making more than $10 \%$ of Italian GDP, i.e. more than the car or tourism industries?!"). Furthermore, when the estimates were discussed with staff of international organizations actively involved in the development of policies against organised crime, an official whispered, "well, you could have produced higher figures...you know...", suggesting that the estimates were not "high enough".

Despite the pessimism, there were also some encouraging signals. For example, a police official praised the study, particularly because "somebody has finally stopped talking about the 'Ndrangheta's monopoly of the cocaine market". He then cited an analysis of serious drug cases investigated in the past two years in the area around Milan. The data showed than only a minority of the cases involved the 'Ndrangheta, despite constant media attention in the same period. This exchange echoed Reuter's 
comments on the "demoralizing impact on lower level officials of having to work with numbers that they know are seriously in error". 59

\section{References}

Albanese, Giuseppe, and Giuseppe Marinelli. "Organized Crime and Productivity: Evidence from Firm-level Data." Rivista Italiana Degli Economisti 18, no. 3 December 2013 (2013): 367-394.

Allum, Felia. Camorristi, Politicians, and Businessmen: The Transformation of Organized Crime in Post-War Naples. Italian Perspectives 11. Leeds, UK: Northern Universities Press, 2006.

Andreas, Peter, and Kelly M Greenhill, eds. Sex, Drugs, and Body Counts: The Politics of Numbers in Global Crime and Conflict. Ithaca, N.Y.: Cornell University Press, 2010. Ardizzi, Guerino, Carmelo Petraglia, Massimiliano Piacenza, Friedrich Schneider, and Gilberto Turati. “Estimating Money Laundering through a 'Cash Deposit Demand' Approach.” Pavia, 2012. http://www-3.unipv.it/websiep/prog2012.htm.

Ardizzi, Guerino, Carmelo Petraglia, Massimiliano Piacenza, and Gilberto Turati. Measuring the Underground Economy with the Currency Demand Approach: a Reinterpretation of the Methodology, with an Application to Italy. Temi Di Discussione (working Papers). Rome: Banca d'Italia, April 2012.

Argentiero, Amedeo, Michele Bagella, and Francesco Busato. "Money Laundering in a Two-sector Model: Using Theory for Measurement.” European Journal of Law and Economics 26, no. 3 (October 7, 2008): 341-359. doi:10.1007/s10657-008-9074-6.

Becchi, Ada. "Italy: 'Mafia-dominated Drug Market'?” In European Drug Policies and Enforcement, edited by Nicholas Dorn, Jorgen Jepsen, and Ernesto Ugo Savona, 119130. Basingstoke and London: Macmillan, 1996.

Behan, Tom. The Camorra. London and New York: Routledge, 1996. 
Calderoni, Francesco. “A Definition That Does Not Work: The Impact of the EU Framework Decision on the Fight Against Organized Crime." Common Market Law Review 49, no. 4 (2012): 1365-1393.

__. "La misurazione dell'infiltrazione della criminalità organizzata negli appalti." In La geografia criminale degli appalti: le infiltrazioni della criminalità organizzata negli appalti pubblici nel Sud Italia, edited by Francesco Calderoni and Stefano Caneppele, 13-31. Milano: Franco Angeli, 2009.

—. "The Structure of Drug Trafficking Mafias: The 'Ndrangheta and Cocaine." Crime, Law and Social Change 58, no. 3 (October 1, 2012): 321-349. doi:10.1007/s10611-012-9387-9.

_ . "Where Is the Mafia in Italy? Measuring the Presence of the Mafia Across Italian Provinces." Global Crime 12, no. 1 (2011): 41. doi:10.1080/17440572.2011.548962.

Carrapiço, Helena. "Chasing Mirages? Reflections on Concepts of Security through the Study of the Securitization of Organized Crime.” San Francisco, 2008.

Catanzaro, Raimondo. "La mafia tra mercato e stato." In La mafia, le mafie: Tra vecchi e nuovi paradigmi, edited by Giovanni Fiandaca and Salvatore Costantino, 177-193. Roma: Laterza, 1994.

Centorrino, Mario, and Ferdinando Ofria. “Criminalità organizzata e produttività del lavoro nel Mezzogiorno: un'applicazione del modello 'Kaldor-Verdoorn'.” Rivista economica del Mezzogiorno no. 1/2008 (2008): 163-187. doi:10.1432/27151.

Coniglio, Nicola D., Giuseppe Celi, and Cosimo Scagliusi. Organized Crime, Migration and Human Capital Formation: Evidence from the South of Italy. Working paper. Southern European Research in Economic Studies. Bari: Università degli studi di Bari, 2010. 
CPA. Relazione sulla prima fase dei lavori della Commissione, con particolare riguardo al condizionamento delle mafie sull'economia, sulla societa`e sulle istituzioni del Mezzogiorno. Roma: Commissione parlamentare di inchiesta sul fenomeno della mafia e sulle altre associazioni criminali, anche straniere, January 25, 2012.

Daniele, Vittorio, and Ugo Marani. "Organized Crime, the Quality of Local Institutions and FDI in Italy: A Panel Data Analysis.” European Journal of Political Economy 27, no. 1 (2010): 132-142. doi:10.1016/j.ejpoleco.2010.04.003.

Dorn, Nicholas. "The End of Organised Crime in the European Union." Crime, Law and Social Change 51 (2009): 283-295.

Dorn, Nicholas, Michael Levi, and Leslie King. Literature Review on Upper Level Drug Trafficking. London: Home Office, 2005.

Euronews. "Taking on Organised Crime." Euronews, April 4, 2012. http://www.euronews.com/2012/04/01/taking-on-the-mafia/. European Commission. Confiscated Assets, 2012. http://www.youtube.com/watch?v=DUWhIXNPcx4\&feature=youtube_gdata_player. —. "Proposal for a Directive of the European Parliament and of the Council on the Freezing and Confiscation of Proceeds of Crime in the European Union COM(2012) 85 Final," March 12, 2012.

Galullo, Roberto. “Mafia Spa, in Cassa 65 Miliardi.” Il Sole 24 ORE, January 10, 2012. http://www.ilsole24ore.com/art/economia/2012-01-11/mafia-cassa-miliardi064340.shtml? uuid=AaSM3fcE.

Gambetta, Diego. The Sicilian Mafia: The Business of Private Protection. Harvard University Press, 1996.

Hagan, Frank E. Introduction to Criminology: Theories, Methods, and Criminal Behavior. 7th ed. Thousand Oaks: Sage, 2011. 
Il Sole 24 ORE. "Le ricette di Ingroia contro la crisi: una banca pubblica e la confisca dei beni agli evasori." Il Sole 24 ORE, February 11, 2013.

http://www.ilsole24ore.com/art/notizie/2013-02-11/ricette-ingroia-contro-crisi160121.shtml?uuid=AbeuNKTH.

Lavezzi, Andrea Mario. "Economic Structure and Vulnerability to Organised Crime:

Evidence from Sicily." Global Crime 9, no. 3 (2008): 198-220.

Le monde. "Le crime organisé, une manne de 870 milliards de dollars annuels," July 24, 2013. http://www.lemonde.fr/economie/article/2013/07/24/le-crime-organise-unemanne-financiere-de-870-milliards-de-dollars-annuels_3453066_3234.html. Mackenzie, James. “Mafia Now Italy’s No.1 Bank as Crisis Bites: Report.” Reuters. January 10, 2012. http://www.reuters.com/article/2012/01/10/us-italy-mafiaidUSTRE8091YX20120110.

Paoli, Letizia. Illegal Drug Markets in Frankfurt and Milan. Lisbon: European Monitoring Centre for Drugs and Drug Addiction, 2000.

—. "Mafia and Organised Crime in Italy: The Unacknowledged Successes of Law Enforcement." West European Politics 30, no. 4 (2007): 854.

—. Mafia Brotherhoods. Organized Crime Italian Style. New York: Oxford University Press, 2003.

http://books.google.it/books/about/Mafia_brotherhoods.html?hl=it\&id=qX5NfHTWzS0 C.

__. "The Illegal Drugs Market.” Journal of Modern Italian Studies 9, no. 2 (2004): $186-207$.

_. "The Paradoxes of Organized Crime." Crime, Law and Social Change 37 (2002): 51-97. 
Paoli, Letizia, and Cyrille Fijnaut. "Introduction to Part I: The History of the Concept." In Organised Crime in Europe: Concepts, Patterns and Control Policies in the European Union and Beyond, edited by Cyrille Fijnaut and Letizia Paoli, 21-46. Dordrecht: Springer, 2004.

Paoli, Letizia, and Peter Reuter. "Drug Trafficking and Ethnic Minorities in Western Europe.” European Journal of Criminology 5, no. 1 (2008): 13-37.

Pearsons, Geoffrey, and Dick Hobbs. Middle Market Drug Distribution. London: Home Office, 2001.

Pinotti, Paolo. The Economic Consequences of Organized Crime: Evidence from Southern Italy. Temi Di Discussione (working Papers). Roma: Banca d'Italia, April 2012. Reuter, Peter. Disorganized Crime. The Economics of the Visible Hand. Cambridge: MIT Press., Cambridge, 1983.

—. "The (continued) Vitality of Mythical Numbers." The Public Interest 75 (1984): 135-147.

—. "The Mismeasurement of Illegal Drug Markets: The Implications of Its Irrelevance." In Exploring the Underground Economy: Studies of Illegal and Unreported Activity, edited by Susan Pozo, 63-80. Kalamazoo: W.E. Upjohn Institute for Employment Research, 1996.

— . "The Social Costs of the Demand for Quantification.” Journal of Policy Analysis and Management 5, no. 4 (July 1, 1986): 807-812. doi:10.2307/3324886.

Reuter, Peter, and John Haaga. The Organization of High-Level Drug Markets: An Exploratory Study. Santa Monica, CA: RAND Corporation, 1989. http://www.rand.org/pubs/notes/N2830. 
Reuters. “Cross-border Criminals Make \$870 Billion a Year: U.N.,” July 12, 2012. http://www.reuters.com/article/2012/07/16/us-crossborder-criminalsidUSBRE86F0DC20120716.

Ruggeri, Amanda. "Taking a Bite Out of Crime in Rome." The New York Times, July 4, 2013, sec. Travel. http://www.nytimes.com/2013/07/07/travel/taking-a-bite-out-ofcrime-in-rome.html.

Santino, Umberto. Dalla mafia alle mafie: scienze sociali e crimine organizzato. Soveria Mannelli: Rubbettino, 2006.

Saviano, Roberto. Gomorra: Viaggio Nell'impero Economico e Nel Sogno Di Dominio Della Camorra. Mondadori, 2006.

—_. "Mafie, i Padroni Della Crisi Perché i Boss Non Fanno Crac.” Repubblica.it, August 27, 2012.

http://www.repubblica.it/cronaca/2012/08/27/news/saviano_criminalit_padrona_della_fi nanza-41551075/?ref=search.

Shafer, Jack. “The (Ongoing) Vitality of Mythical Numbers.” Slate, June 26, 2006. http://www.slate.com/articles/news_and_politics/press_box/2006/06/the_ongoing_vitali ty_of_mythical_numbers.html.

Singer, Max. "The Vitality of Mythical Numbers.” The Public Interest 23 (1971): 3-9.

Sky Tg24. "Sos Impresa: 'Mafia Spa è La Prima Banca d’Italia' - Tg24 - Sky.it,” January $10,2012$. http://tg24.sky.it/tg24/economia/2012/01/10/mafia_prima_banca_italia.html. Smith, Dwight C. The Mafia mystique. New York, NY: Basic Books, 1975. SOS Impresa. Le mani della criminalità sulle imprese. Roma: Confesercenti, 2006. Le mani della criminalità sulle imprese. Roma: Confesercenti, 2012. 
__. "SOS Impresa: 'Mafia Spa è la prima banca d'Italia'," 2012.

http://www.sosimpresa.it/1167/sos-impresa-mafia-spa-e-la-prima-banca-ditalia.html. Tarantola, Anna Maria. Dimensione Delle Attività Criminali, Costi Per L'economia, Effetti Della Crisi Economica. Roma: Commissione parlamentare di inchiesta sul fenomeno della mafia e sulle altre associazioni criminali, anche straniere, June 6, 2012. http://www.ilsole24ore.com/pdf2010/SoleOnLine5/_Oggetti_Correlati/Documenti/Noti zie/2012/06/bankitaliantimafia2012.pdf?uuid=826d0b16-afd4-11e1-b41028ed72f00729.

Transcrime. Progetto PON Sicurezza 2007-2013: Gli investimenti delle mafie. Rapporto Linea 1. Milano: Ministero dell'Interno, 2013. www.investimentioc.it.

Tribunale di Milano. Ordinanza di applicazione di misura coercitiva con mandato di cattura - art. 292 c.p.p. (Operazione Infinito) (Ufficio del giudice per le indagini preliminari 2011).

UNODC. Estimating Illicit Financial Flows Resulting from Drug Trafficking and Other Transnational Organized Crimes. Research Report. Vienna: United Nations Office on Drugs and Crime, October 2011. http://www.unodc.org/documents/data-andanalysis/Studies/Illicit_financial_flows_2011_web.pdf.

—_. "Transnational Crime Proceeds in Billions, Victims in Millions, Says UNODC Chief," 2012. http://www.unodc.org/unodc/en/press/releases/2012/October/transnational-crimeproceeds-in-billions-victims-in-millions-says-unodc-chief.html.

__. "Transnational Organized Crime: Let’s Put Them Out of Business,” 2012. https://www.unodc.org/toc/.

Van Duyne, Petrus C. “Introduction: Counting Clouds and Measuring Organised Crime." In The Organisation of Crime for Profit: Conduct, Law and Measurement, ed- 
ited by Petrus C. van Duyne, Almir Maljevic, Maarten van Dijck, Klaus von Lampe, and James L. Newell. Nijmegen: Wolf Legal Publishers, 2006.

—_. "The Creation of a Threat Image: Media, Policy Making and Organised Crime." In Threats and Phantoms of Organised Crime, Corruption and Terrorism, edited by Petrus C. van Duyne, Matjaž Jager, Klaus von Lampe, and James L. Newell, 2150. Nijmegen: Wolf Legal Publishers, 2004.

Van Duyne, Petrus C., and Tom Vander Beken. "The Incantations of the EU Organised Crime Policy Making.” Crime, Law and Social Change 51 (2009): 261-281.

Varese, Federico. "How Mafias Migrate: The Case of the 'Ndrangheta in Northern Italy." Law \& Society Review 40, no. 2 (June 2006): 411-444.

—. Mafias on the Move: How Organized Crime Conquers New Territories. Princeton University Press, 2011.

Von Lampe, Klaus. "Not a Process of Enlightenment: The Conceptual History of Organized Crime in Germany and the United States of America." Forum on Crime and Society 1 , no. 2 (2001): 99-116.

Woodiwiss, Michael. "Transnational Organized Crime: The Strange Career of an American Concept.” In Critical Reflections on Transnational Organized Crime, Money Laundering and Corruption, edited by Margaret E. Beare, 3-34. Toronto: University of Toronto Press, 2003.

Woodiwiss, Michael, and Dick Hobbs. "Organized Evil and the Atlantic Alliance.” British Journal of Criminology 49, no. 1 (January 1, 2009): 106-128.

Za, Valentina. "Italy’s Crisis Opens Doors to Cash-rich Mafia.” Reuters. January 13, 2012. http://www.reuters.com/article/2012/01/13/us-italy-mafia-crisisidUSTRE80C16320120113. 
${ }^{1}$ Singer, "The Vitality of Mythical Numbers," 6; Reuter, "The (continued) Vitality of Mythical Numbers"; Shafer, "The (Ongoing) Vitality of Mythical Numbers."

${ }^{2}$ Singer, "The Vitality of Mythical Numbers," 6.

${ }^{3}$ Reuter, "The (continued) Vitality of Mythical Numbers," 145-146.

${ }^{4}$ Reuter, "The Social Costs of the Demand for Quantification," 807.

${ }^{5}$ Ibid., 811.

${ }^{6}$ Shafer, "The (Ongoing) Vitality of Mythical Numbers"; Andreas and Greenhill, Sex, Drugs, and Body Counts; Hagan, Introduction to Criminology, 442.

${ }^{7}$ Woodiwiss, "Transnational Organized Crime: The Strange Career of an American Concept"; Paoli and Fijnaut, "Introduction to Part I: The History of the Concept."

${ }^{8}$ Woodiwiss and Hobbs, "Organized Evil and the Atlantic Alliance"; Carrapiço, "Chasing Mirages? Reflections on Concepts of Security through the Study of the Securitization of Organized Crime."

${ }^{9}$ Smith, The Mafia mystique; Reuter, Disorganized Crime. The Economics of the Visible Hand; Paoli, "The Paradoxes of Organized Crime"; van Duyne, "The Creation of a Threat Image: Media, Policy Making and Organised Crime.”

${ }^{10}$ von Lampe, "Not a Process of Enlightenment: The Conceptual History of Organized Crime in Germany and the United States of America"; van Duyne, "Introduction: Counting Clouds and Measuring Organised Crime"; Dorn, "The End of Organised Crime in the European Union"; van Duyne and Vander Beken, "The Incantations of the EU Organised Crime Policy Making”; Calderoni, “A Definition That Does Not Work: The Impact of the EU Framework Decision on the Fight Against Organized Crime."

${ }^{11}$ UNODC, Estimating Illicit Financial Flows Resulting from Drug Trafficking and Other Transnational Organized Crimes, 34.

${ }^{12}$ UNODC, "Transnational Crime Proceeds in Billions, Victims in Millions, Says UNODC Chief." 
${ }^{13}$ UNODC, "Transnational Organized Crime: Let's Put Them Out of Business"; Le monde, "Le crime organisé, une manne de 870 milliards de dollars annuels"; Reuters, "Cross-border Criminals Make \$870 Billion a Year: U.N.”

${ }^{14}$ Reuter, "The Social Costs of the Demand for Quantification," 810.

${ }^{15}$ Ibid., 809; Paoli, "Mafia and Organised Crime in Italy."

${ }^{16}$ Reuter, "The Mismeasurement of Illegal Drug Markets: The Implications of Its Irrelevance."

${ }^{17}$ Reuter, "The Social Costs of the Demand for Quantification," 810.

18 Transcrime, Progetto PON Sicurezza 2007-2013: Gli investimenti delle mafie. Rapporto Linea 1.

${ }^{19}$ Singer, "The Vitality of Mythical Numbers."

${ }^{20}$ Argentiero, Bagella, and Busato, "Money Laundering in a Two-sector Model."

${ }^{21}$ Ardizzi et al., Measuring the Underground Economy with the Currency Demand Approach: a Reinterpretation of the Methodology, with an Application to Italy.

${ }^{22}$ Ardizzi et al., "Estimating Money Laundering through a 'Cash Deposit Demand' Approach."

${ }^{23}$ Tarantola, Dimensione Delle Attività Criminali, Costi Per L'economia, Effetti Della Crisi Economica., 5.

${ }^{24} \mathrm{CPA}$, Relazione sulla prima fase dei lavori della Commissione, con particolare riguardo al condizionamento delle mafie sull'economia, sulla societa`e sulle istituzioni del Mezzogiorno, 15 .

${ }^{25}$ European Commission, "Proposal for a Directive of the European Parliament and of the Council on the Freezing and Confiscation of Proceeds of Crime in the European Union $\operatorname{COM}(2012) 85$ Final," 2.

${ }^{26}$ European Commission, Confiscated Assets.

${ }^{27}$ Euronews, "Taking on Organised Crime"; Ruggeri, "Taking a Bite Out of Crime in Rome"; Za, "Italy’s Crisis Opens Doors to Cash-rich Mafia."

${ }^{28}$ SOS Impresa, Le mani della criminalità sulle imprese, 2006. 
${ }^{29}$ SOS Impresa, Le mani della criminalità sulle imprese, 2012, 47-48.

${ }^{30}$ UNODC, Estimating Illicit Financial Flows Resulting from Drug Trafficking and Other Transnational Organized Crimes, 61.

${ }^{31}$ Ibid., 26.

${ }^{32}$ Galullo, "Mafia Spa, in Cassa 65 Miliardi”; Saviano, "Mafie, i Padroni Della Crisi Perché i Boss Non Fanno Crac"; Sky Tg24, "Sos Impresa"; Mackenzie, "Mafia Now Italy’s No.1 Bank as Crisis Bites."

${ }^{33}$ SOS Impresa, "SOS Impresa: 'Mafia Spa è la prima banca d'Italia'."

${ }^{34}$ Il Sole 24 ORE, "Le ricette di Ingroia contro la crisi."

35 Transcrime, Progetto PON Sicurezza 2007-2013: Gli investimenti delle mafie. Rapporto Linea 1.

${ }^{36}$ Reuter and Haaga, The Organization of High-Level Drug Markets: An Exploratory Study; Pearsons and Hobbs, Middle Market Drug Distribution; Dorn, Levi, and King, Literature Review on Upper Level Drug Trafficking.

${ }^{37}$ Becchi, "Italy: 'Mafia-dominated Drug Market'?"; Paoli, Illegal Drug Markets in Frankfurt and Milan; Paoli, "The Paradoxes of Organized Crime"; Paoli, "The Illegal Drugs Market"; Varese, "How Mafias Migrate"; Paoli and Reuter, "Drug Trafficking and Ethnic Minorities in Western Europe."

${ }^{38}$ Transcrime, Progetto PON Sicurezza 2007-2013: Gli investimenti delle mafie. Rapporto Linea 1 .

${ }^{39}$ Calderoni, "La misurazione dell'infiltrazione della criminalità organizzata negli appalti"; Calderoni, "Where Is the Mafia in Italy?".

${ }^{40}$ The DIA is a national law enforcement agency tasked with the fight against the mafias and organized crime. It is composed of officers from the three main Italian law enforcement agencies, namely the State Police, the Carabinieri and the Guardia di Finanza. The DNA is a national coordinating body consisting of 20 senior prosecutors. Its main task is to coordinate 
the prosecution of mafia and organized crime cases. To this end, it encourages information sharing and the coordination of investigations among 26 Antimafia District Directorates, these being special bodies established within the prosecutor's offices in cities where a Court of Appeal is based.

${ }^{41}$ In regard to the DNA annual reports, it was not possible to find the 2003 report. This document was requested from both the DNA and the library of the Antimafia Parliamentary Commission, but to no avail.

${ }^{42}$ The information was entered into two databases at municipal level, one for the DIA and one for the DNA. The following variables were developed from the information extracted for each report: presence of groups in the municipality/province; number of groups in the municipality/province; names of the groups in the municipality/province; number of groups belonging to each type of mafia organization in the municipality/province. Finally, the two databases were combined to calculate the sum and the average of the variables listed above. For further details on the methodology, see Transcrime Progetto PON Sicurezza 2007-2013: Gli investimenti delle mafie. Rapporto Linea 1.

${ }^{43}$ The aggregation weighted the scores for each municipality in the province/region with the average resident population between 2004 and 2011.

${ }^{44}$ Calderoni, "Where Is the Mafia in Italy?".

${ }^{45}$ Gambetta, The Sicilian Mafia; Varese, Mafias on the Move.

${ }^{46}$ Some scholars have criticized this approach mainly because of its alleged incapacity to explain the origin of the demand for private protection (Catanzaro, "La mafia tra mercato e stato"; Santino, Dalla mafia alle mafie). Despite these criticisms, the approach has the merit of highlighting the importance of extortion and protection for mafias, thus bringing about a new focus which has been at least partially shared also by the main critics.

${ }^{47}$ Reuter, Disorganized Crime. The Economics of the Visible Hand; Paoli, Mafia Brotherhoods. Organized Crime Italian Style.

${ }^{48}$ Paoli, "The Paradoxes of Organized Crime." 
${ }^{49}$ Lavezzi, "Economic Structure and Vulnerability to Organised Crime."

${ }^{50}$ Pinotti, The Economic Consequences of Organized Crime: Evidence from Southern Italy.

${ }^{51}$ Albanese and Marinelli, “Organized Crime and Productivity: Evidence from Firm-level Data."

${ }^{52}$ Daniele and Marani, "Organized Crime, the Quality of Local Institutions and FDI in Italy."

${ }^{53}$ Tribunale di Milano, Ordinanza di applicazione di misura coercitiva con mandato di cattura art. 292 c.p.p. (Operazione Infinito) (Ufficio del giudice per le indagini preliminari 2011).

${ }^{54}$ Pinotti, The Economic Consequences of Organized Crime: Evidence from Southern Italy; Coniglio, Celi, and Scagliusi, Organized Crime, Migration and Human Capital Formation: Evidence from the South of Italy; Centorrino and Ofria, "Criminalità organizzata e produttività del lavoro nel Mezzogiorno"; Daniele and Marani, "Organized Crime, the Quality of Local Institutions and FDI in Italy"; Lavezzi, "Economic Structure and Vulnerability to Organised Crime.”

${ }^{55}$ Paoli, "Mafia and Organised Crime in Italy."

${ }^{56}$ Saviano, Gomorra.

${ }^{57}$ Behan, The Camorra; Allum, Camorristi, Politicians, and Businessmen.

${ }^{58}$ Paoli, Mafia Brotherhoods. Organized Crime Italian Style; Varese, "How Mafias Migrate"; Calderoni, "The Structure of Drug Trafficking Mafias."

${ }^{59}$ Reuter, "The (continued) Vitality of Mythical Numbers," 146 footnote 11. 